技術資料

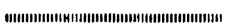

UDC $\quad 621.77: 669.14 .018 .8$

\title{
ステンレス鋼圧延技術の進歩*
}

佐々木進**

\section{Development of Rolling and Processing Practice in Stainless Steel Production}

\author{
Susumu SASAKI
}

\section{1. 緒}

言

ステンレス鋼は耐食性，耐熱性などに優れていること が一般に認識され，原子力産業用から家庭用にいたるま で非常に幅広く使用されるようになり，最近 10 年間の 生産量の伸びは著しい，熱間圧延鋼带でみると昭和38年 17 万 $\mathrm{t}$ から昭和 47 年 66 万 $\mathrm{t}$ に, 冷間仕上げ鋼材では 同様に 15 万 $\mathrm{t}$ から 50 万 $\mathrm{t} に ，$ 約 4 倍となつている. それにともなつて，設備および技術面での進歩にめざま しいものがあり，今や普通鋼なみの大量生産方式に近接 した観がある.

ステンレス鋼带の熱延および冷延技術の進歩の過程を 要約すると次のとおりである.

(a) 広幅センジミア圧延機の導入に端を発した冷延 技術の進歩

（b）生産規模の増大により，連続式ホットストリッ プ圧延機以外にステンレス鋼専用の新熱延圧延機を設置 するなど，製鋼から冷延までの一貫生産体制の確立

（c）センジミア圧延機の大型化，高速化および厚子 制御などの自動化

（d） センジそア圧延機のタンデム化

（e）連続焼鈍炉の加熱技術の進歩および新脱スケー ル方法の開発

（f） テンションレベラの開発などによる精整工程の 合理化

昭和 40 年台はとくに，新技術の開発による生産性の 飛躍的向上が認められ，省力，コストダウンなど多大な 成果を収めた. 同時に, 高度の技術と改善努力による品 質水準の向上も著しいものがある.

鋼板, 形鋼，管材などの技術についても著しい進歩が 認められるが，本諭では省略する。

（注） 昭和 37 年より 47 年までの熱間圧延鋼材およ び冷間仕上げ鋼材の生産実續の推移を図 1 亿示
す.

\section{2. 分塊圧延}

\section{1 ステンレス鋼塊の熱間加工性}

ステンレス鋼の熱間加工性はきわ好て悪く, 分塊圧延 は非常に難しいものと考光られていたが，熱間加工性に 関する各種の研究や製鋼技術の進歩によつて, 現在では いろいろなステンレス鋼種の広幅帯鋼が 5〜12 $\mathrm{t}$ の大型 鋼塊，あるいは連続鋳造や加圧鋳造のスラブなどから製 造されている. 1972 年に改正された JIS (G4306)熱間 圧延ステンレス鋼帯に規定された鋼種を表 1 亿示した。

マルテンサイト系やオーステナイト系ステンレス鋼の 中には分塊圧延の際割れやすいものがあり，なかでも SUS 631 は高温で 20\% 程度のフェライトを析出し, 2 相組織になるので，スラブの表面に写真 1 に示すような 屋根瓦状割れが発生しやすく，大型鋼塊の分塊は難しい と考元られていたが，特殊元素の添加などによつてこの ようなバランス不良鋼種の大型鋼塊からの量産化も可能 になつた。

\section{2 分塊压延方法}

分塊圧延機や均熱炉その他の付带設備などについては すでに詳述されており，ステンレス鋼としてとくに違つ たところは少ないので省略するが，圧延機の強大化によ つて鋼塊が大型化し, 5〜12 $\mathrm{t}$ 鋼塊から厚さ120〜150 mm 最大幅 $1600 \mathrm{~mm}$ のスラブが 20〜25 パスで分塊される ようになつた・オーステナイト采鋼種の場合，大型鋼塊 としてとくに問題はないが，フェライト系鋼種では次の ような異常が現われやすい（a 凝固時に鋼塊の表面に 割れが発生しやすく，スラブの疪取歩留が低下する.

(b)冷塊になると加熱時の熱ショックで写真 2 に示すよ

* 昭和 48 年 5 月 19 日受付 (依頼技術資料)

** 日新製鋼 (株) 


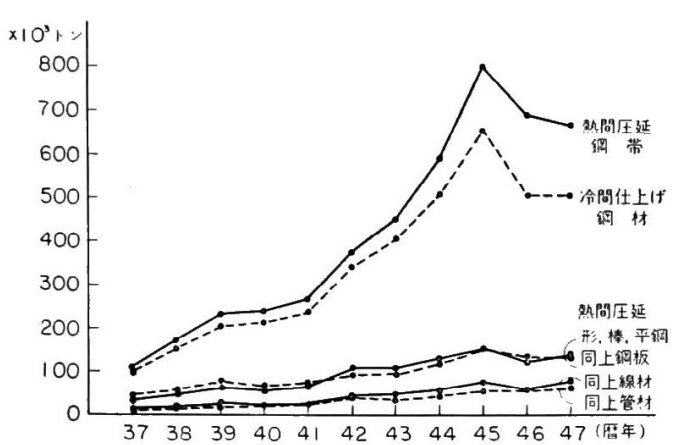

図 1 熱間圧延および冷間仕上げ鋼材生産実績 (ステンレス協会統計資料)

表 1 熱間圧延ステンレス鋼带 (JISG4306)鋼種

\begin{tabular}{|c|c|c|}
\hline 区 & 主 成 分 & J I S 鋼種 \\
\hline マルテンサイト采 & $\begin{array}{l}\text { 低 } \mathrm{C}-\mathrm{Cr} \\
\text { 中 } \mathrm{C}-\mathrm{Cr} \\
\text { 高 } \mathrm{C}-\mathrm{Cr}\end{array}$ & $\begin{array}{l}403,410 \\
420 \mathrm{~J} 1 \\
440 \mathrm{~A}\end{array}$ \\
\hline フェライト采 & $\begin{array}{l}\mathrm{Cr} \\
\mathrm{Cr} \text {-Al } \\
\mathrm{Cr} \text {-Mo }\end{array}$ & $\begin{array}{l}429, \quad 430 \\
405 \\
434\end{array}$ \\
\hline 2 相 系 & 低 $\mathrm{Ni}-\mathrm{Cr}-\mathrm{Mo}$ & $329 \mathrm{~J} 1$ \\
\hline オーステナイト采 & $\begin{array}{l}\mathrm{Ni}-\mathrm{Cr} \\
\mathrm{Ni}-\mathrm{Cr}-\mathrm{Mo} \\
\mathrm{Ni}-\mathrm{Cr}-\mathrm{Mo}-\mathrm{Cu} \\
\mathrm{Ni}-\mathrm{Cr}-\mathrm{Mn} \\
\mathrm{Ni}-\mathrm{Cr}-\mathrm{Ti} \\
\mathrm{Ni}-\mathrm{Cr}-\mathrm{Nb}\end{array}$ & $\begin{array}{l}301,302,304, \\
304 \mathrm{~L}, 309 \mathrm{~S}, 310 \mathrm{~S} \\
316,316 \mathrm{~L}, 317 \\
317 \mathrm{~L} \\
316 \mathrm{~J} 1,316 \mathrm{~J} 1 \mathrm{~L} \\
201,202 \\
321 \\
347\end{array}$ \\
\hline 析出硬化系 & $\mathrm{Ni}-\mathrm{Cr}-\mathrm{Al}$ & 631 \\
\hline
\end{tabular}

うな割れが発生しやすい. ステンレス鋼は熱伝導度が悪 く，鋼種によつては加熱冷却の際割れやすいことから， 大型鋼塊は熱塊処理が好ましい.

分塊後の高温スラブは冷却床で放冷されるのが普通で あるが，オーステナイト采鋼種の場合，スラブクーラー によつて水冷も行なわれている. スラブクーラーは本来 クーリングヤードの面積の節約が目的であつたが，ステ ンレス鋼の場合スラブ表面の硬いスケールが水冷するこ とによつて除去され, グラインダー疪取りの研削能率が 放冷されたものより向上するメリットも期待できる. フ ェライト系やマルテンサイト采鋼種では割れの危険性が あるので行なわれていない.

\section{$2 \cdot 3$ スラブの手入れ}

ステンレス鋼はスラブ加熱時のスケールの発生量が少 なく，スラブの表面欠陷や凹凸などはそのまをホットコ イル表面に持ち込まれ, 表面品質が著しく損なわれるの

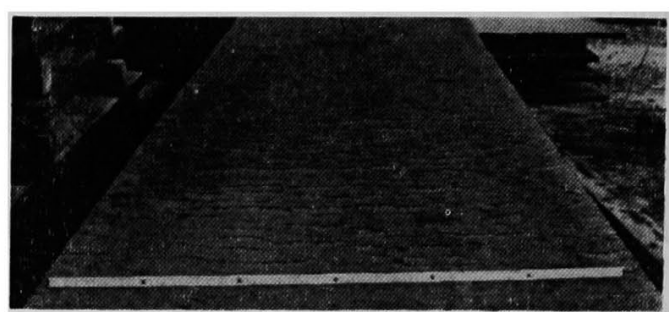

写真 1 SUS 631 の分塊割れ

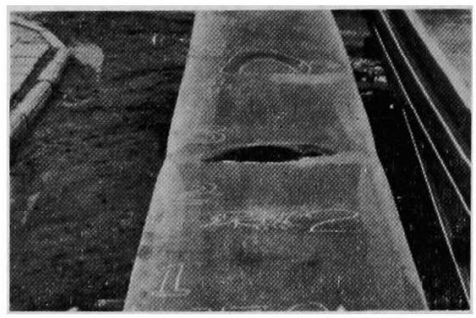

写真 2 SUS 430 冷塊の熱割れ

表 2 超高速自動研削機の設備仕様

\begin{tabular}{|c|c|c|}
\hline 被研削材 & $\begin{array}{l}\text { 材料温度 } \\
\text { 材 質 }\end{array}$ & $\begin{array}{l}\text { 常温 } 9900^{\circ} \mathrm{C} \\
\text { 各種ステンレス鋼, 特殊鋼 }\end{array}$ \\
\hline 研 削 材 & $\begin{array}{l}\text { 低石寸法 } \\
\text { " 周速 } \\
\text { " 回転数 } \\
\text { " 压着力 } \\
\text { " 傾斜角度 } \\
\text { 台車走行速度 }\end{array}$ & $\begin{array}{l}610 \phi \times 710 \times 0,203 \cdot 2 \phi \\
\operatorname{Max} 4870 \mathrm{~m} / \mathrm{min} \\
2540,2810,3120,3480 \\
\text { PRM 4 段変速 } \\
150 \sim 650 \mathrm{~kg} \\
45^{\circ} \\
0 \sim 30 \mathrm{~m} / \mathrm{min} \text { (自動) }\end{array}$ \\
\hline
\end{tabular}

で最近ではとくに入念な手入れが行なわれている.プレ ーナーによる切削疵取は仕上面が非常にきれいであり， グラインダー㾟取りで割れやすい鋼種も処理でき，スク ラップの回収も完全に行なえるなどの利点をもつが，超 高速自動研削機の開発によりこの低石疵取方式が一般化 している. 超高速自動研削機の設備仕様の 1 例を表 2 に 示す.

この研削機は高能率であると同時に低石の角度が走行 方向に対して $45^{\circ}$ でありかつ高周速のために研削仕上 面の凹凸が比較的小さい. その他温間疵取りの可能なこ ともきわめて大きな長所である. フェライト系やマルテ ンサイト系鋼種は部分的に重研削すると割れが発生しや すく，その防止法としては $200 \sim 500^{\circ} \mathrm{C}$ の温間で研削す るのが最も効果的である. また通常の泠却条件ではスラ ブの表面が焼入れ状態となる鋼種は，Ms 点以上の温度 で研削を終了させることが必要であり，このような作業 も容易に行なわれるようになつた. SUS 430 などを温 間疪取すると低石の研削量が 4〜 5\% 向上するが，仕上 面が粗くなるので低石の粒度調整が必要である. 


\section{4 その他}

連続鋳造や加圧鋳造技術の進歩はめざをしく, 鋳造が 難しいといわれた SUS 430 なども現在では問題なく製 造されるようになつた. 表1のなかで鋳造に問題のある 鋼種は数鋼種にすぎず，この残された鋼種も近い将来鋳 造技術が完成するであるう.

作業の機械化, 自動化, 連続化, などの合理化のなか で造塊方式から連鋳方式への移行は最も生産性を高め, コストを低減させる方法であり，ステンレス鋼の分野で はとくに推進されるであろう.

\section{3. 熱 間 圧 延}

ステンレス鋼の広幅の熱延鋼帯の製造方式としては夕 ンデム圧延機，ステッケル压延機およびプラネタリ圧 延機による圧延が採用されている.ストリップの幅は夕 ンデム圧延機による圧延では最高 $1600 \mathrm{~mm}$ までのもの が製造され，ステッケル圧延機およびプラネタリ圧延機 による圧延では1 $300 \mathrm{~mm}$ までのものが製造されている.

\section{1 熱間変形抵抗}

ステンレス鋼の熱延は普通鋼に比較して変形抵抗が高 いので強圧下の圧延が行ないがたく, 圧延速度を小さく し，ロールパワーを大きくせざるをえない，ステンレス 鋼の代表的な鋼種の高温における変形抵抗の一例を表 3 に示し, 実際の圧延における变形抵抗を図 2 に示す.

\section{2 熱延銅带の製造方式}

(1) タンデム圧延機による圧延

連続式ホットストリップ压延機は板の需要增加に伴つ て，圧延機の中で最も進歩が著しいものである.

ホットストリップ压延機の設備概要は後に掲載の「熱 間ストリップ圧延機の進歩」を参照されたいが，ステン レス鋼の压延は普通鋼 の圧延設備がそのまま用いられ る. ステンレス鋼の加熱はプッシャ式あるいはウォーキ ングビーム式連続炉が使用されるが普通鋼に比較して熱

表 3 ステンレス鋼の変形抵抗 $\left(\mathrm{kg} / \mathrm{mm}^{2}\right)$

\begin{tabular}{|c|c|c|c|}
\hline 鋼種 & $0.8 / \mathrm{s}$ & $7 / \mathrm{s}$ & $77 / \mathrm{s}$ \\
\hline 普 通 鋼 & $9 \cdot 0$ & $11 \cdot 6$ & $14 \cdot 8$ \\
\hline S U S 410 & $18 \cdot 8$ & $14 \cdot 0$ & $15 \cdot 8$ \\
\hline S U S 304 & $15 \cdot 0$ & $18 \cdot 4$ & $21 \cdot 2$ \\
\hline S US 316 & $19 \cdot 6$ & $21 \cdot 9$ & $24 \cdot 3$ \\
\hline
\end{tabular}

（住）1. 媇形速度 $7 / \mathrm{S}$ は毎秒嫖点距離 $(25 \mathrm{~mm})$ の 7 倍伸びる ような速さを示す

2. 武医温度: $1030^{\circ} \mathrm{C}$

3. 加工度 $: 20 \%$

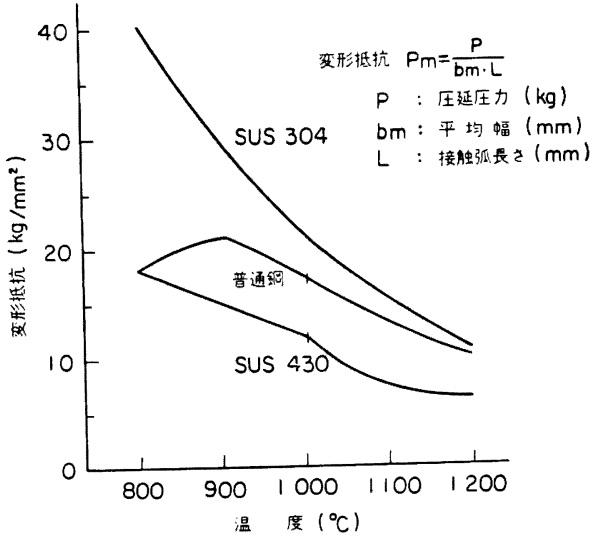

四 2 ステンレス鋼の変形抵抗と温度の関係

伝導が悪く, 約 2 倍の予熱, 均熱が必要とされ，普通， 長時間の加熱がなされている.しかしながら，最近では 生産能率の向上および表面品質向上の要求から, 鋼種に よつてはかなり時間の短縮された急速加熱が行なわれて いる. この点，ウォーキングビーム式加熱炉は 4 面加熱 であるため急速加熱が容易である.

また，スラブとスキッドの接触位置を変えうるよう設 計されており，抽出装置も落下式に代つてスラブエキス トラクターが使用され，プッシャ式に比較してスキッド マークの軽減，へゲ疵の防止などの理由からステンレス 鋼にはとくに利点のあるものといえる.

加熱炉用の熱源としては通常, 重油あるいはガス, 重 油とガスの併用が用いられている．加熱温度は圧延機パ ワーによつて多少異なるが，一般的には

$$
\begin{aligned}
& \text { マルテンサイト系: }: 1100 \sim 1260^{\circ} \mathrm{C} \\
& \text { フェライト系 : } 1100 \sim 1180^{\circ} \mathrm{C} \\
& \text { オーステナイト系 : } 1150 \sim 1260^{\circ} \mathrm{C}
\end{aligned}
$$

である・

また，ステンレス鋼の圧延は普通鋼に比較して变形抵 抗が高いこと，スケールの発生が少ないことなどの特性 から压延速度，デスケーリングの使用，ロール冷却水の 量などが若干異なつた圧延となつているが，コイル単重 の増に伴う寸法精度の維持および向上を目指して，普通 鋼之同様に加速圧延，AGC などの適用も行なわれてい る.

ストリップの素材であるスラブは従来の圧延機では厚 さ $120 \sim 130 \mathrm{~mm}$, 幅 $800 \sim 1600 \mathrm{~mm}$, 単重 $5 \sim 8 \mathrm{t}$ 程度 であるが最新式の圧延機では厚さ $120 \sim 150 \mathrm{~mm}$, 幅 800 〜1600 mm, 単重 $10 \sim 12 \mathrm{t}$ 程度まで拡大されている.

ストリップの厚さは通常, $1000 \mathrm{~mm}$ 幅のとき 3〜4 $\mathrm{mm}$ 程度のものであるが大型の最新式圧延機ではさらに 


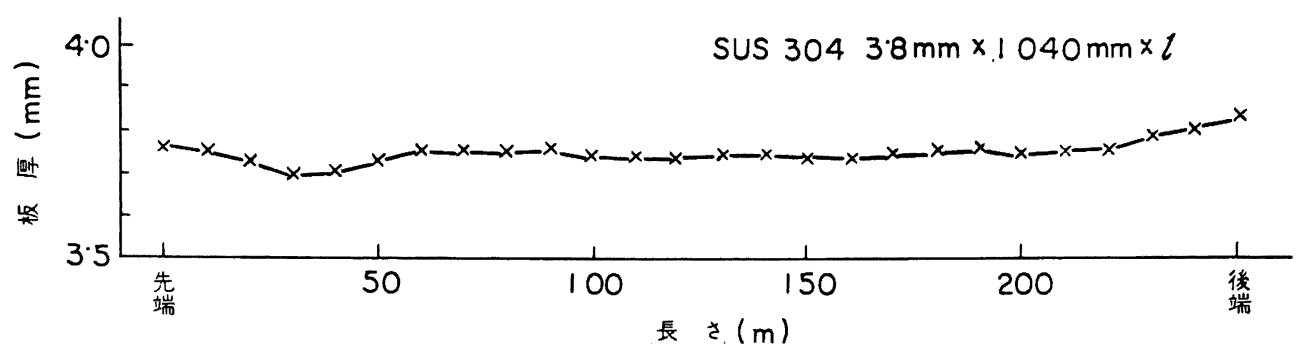

困 3 タンデム圧延機の長手方向の板厚変動

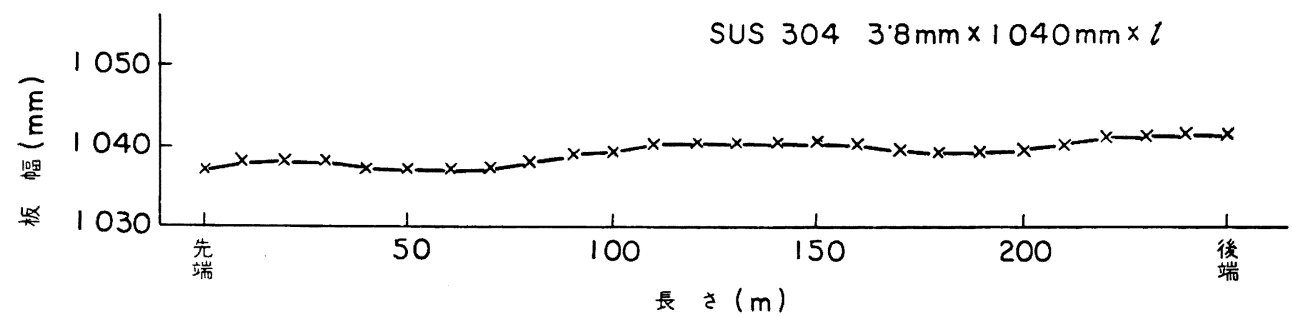

図4 タンデム圧延機の長手方向の板幅変動

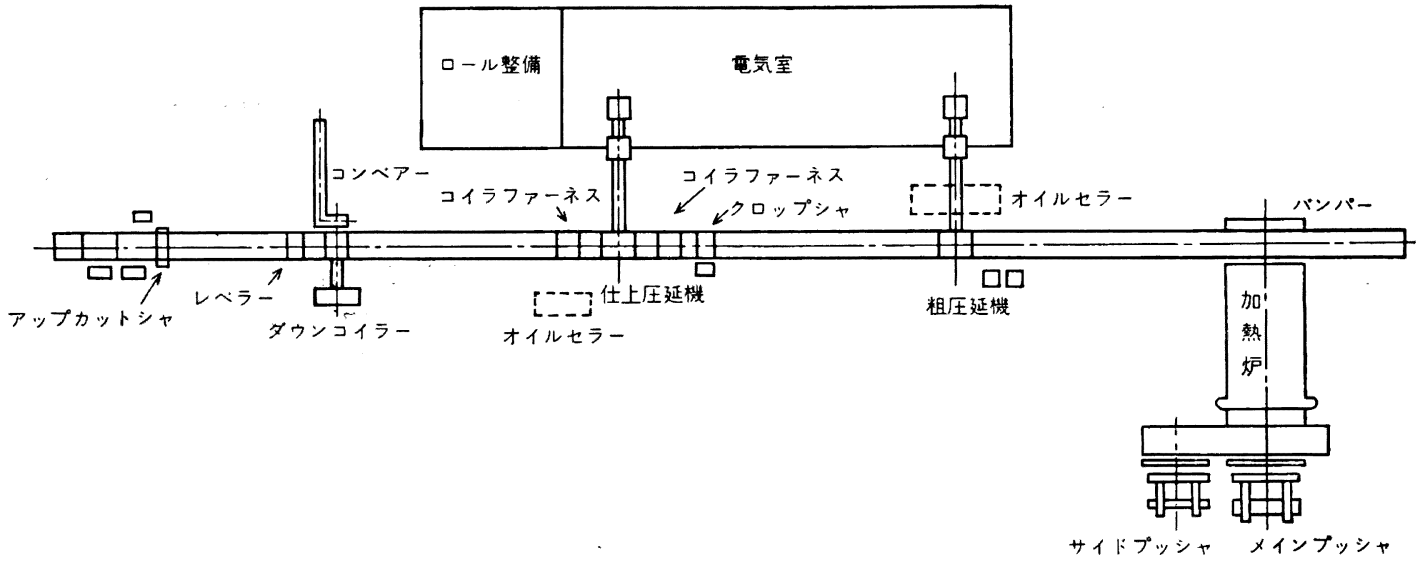

因 5 ステッケル压延機の設備配置（A 社の例）

薄いものまでが圧延されている.

ステンレス鋼の場合は普通鋼に比較して機械設備によ つて疵がつきやすいので, 輸送, 加熱、压延, 巻取の各 段階で注意を要する，とくに，仕上圧延機のガイドおよ び巻取機における機械設備の改善と制御技術に工夫がな されている.

ステンレス鋼のタンデム圧延機で压延された板厚, 板 幅の一例を示すと図 3 , 図 4 の通りであるが，寸法精度 はステッケル圧延機およびプラネタリ瓜延機で圧延され たものより,そのバラツキは少なく良好といえる。また， 表面品質についてもタンデム圧延機で压延された榇り
ップが最も良いといわれている.

（2）ステッケル圧延機による圧延

$\mathrm{A}$ 社の設備配置の一例および世界の保有数を示すと次 のとおりである.

(a) ステッケル压延機の設備配置

(b) ステッケル圧延機の世界の保有数

$\begin{array}{ccccc}\text { 日 } & 2 \text { 台 } & \text { 西 } & \text { 欧 } & 5 \text { 台 } \\ \text { アシシア } & 2 \text { 台 } & \text { 東 } & \text { 欧 } & 1 \text { 台 } \\ \text { 北 米 } & 4 \text { 台 } & \text { ソ 連 } & 3 \text { 台 } \\ \text { 中南米 } & 3 \text { 台 } & \text { 計 } & 20 \text { 台 }\end{array}$

ステッケル圧延機用の加熱炉としては圧延機の能力が 


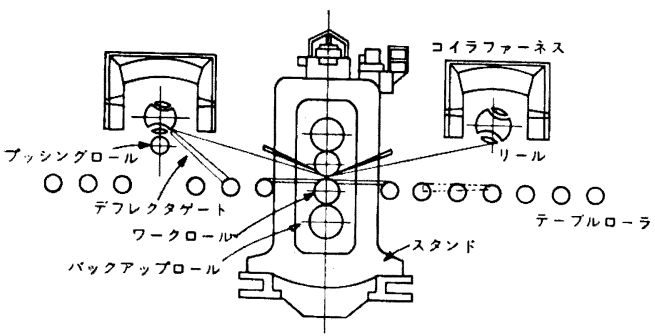

困 6 ステッケル压延譏の構造

仦さいので, 炉長 $15 \mathrm{~m}$ 程度のプッシャ式あるいはウォ 一キングビーム式の連続炉で，加熱能力 $30 \sim 50 \mathrm{t} / \mathrm{hr}$ 程 度のものが使用されている. 加熱炉用熱源は通常, 重油 かガスが使用されているが，灯油を使用しているところ もある. 粗圧延機は通常, 可逆式の四重圧延機が用いら れ, スラブ厚さ $80 \sim 130 \mathrm{~mm}$, 幅 $800 \sim 1300 \mathrm{~mm}$, 単重 5〜7 $\mathrm{t}$ 程度のスラブを 5〜7 パスの圧延で 15〜20 mm 程度の厚さにする. この粗圧延機は均熱炉と組合わせて 分塊圧延を行なつている工場もある。

ステッケル压延機の構造は図 6 に一例を示すように, 四重式の圧延機で正逆の運転を繰返して仕上圧延を行な うが，ストリップの温度降下を防ぐために，圧延機の両 側にコイラフォーネスとよばれる保熱炉を備えている. コイラフォーネスにはストリップ巻取り用として, リー

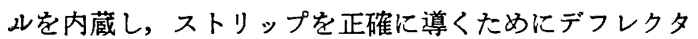

ゲートおよびプッシングロールなどが設置されている.

ステッケル压延機はコイラファーネスとの組合わせで 正逆を繰返して圧延を行なう压延機であるが各機器の構 造が若干異なる型式の圧延機がある。たとえば

(a) コイラフォーネスでは図6に示すような下部が 開放型となつているオープンタイプとストリップの入口 部のみが開いているクローズドタイプのものがある.

（b）コイラフォーネスに内蔵されているリールでは 図 6 に示すようなセグメントタイプと一体構造の単式ス ロットタイプがある.

(c) コイラフォーネスおよびリールの構造によつて はストリップを正確に送り込み，送り出しを行なうため に，压延機とコイラフォーネスの中間にピンチロールを 設けたタイプがある.

コイラフォーネスの炉温は圧延材によつて異なるが， $800 \sim 1100^{\circ} \mathrm{C}$ 程度である.

ステンレス鋼の場合，ステッケル压延機で圧延される ストリップの厚さは 5〜9 パスの繰り返しで, 通常 1000 $\mathrm{mm}$ 幅のとき $3 \sim 5 \mathrm{~mm}$ 程度である. 板厚, 板幅の一例 を示すと，図 7 ，図 8 の通りである.

ステッケル压延機は正逆の運転を繰返して死延を行な うため, ストリップの頭部，尾部の温度降下が中央部に 比較して著しくなり,困７に示すように頭部, 尾部の厚さ が厚くなり,タンデム圧延機に比較して, コイル内の変

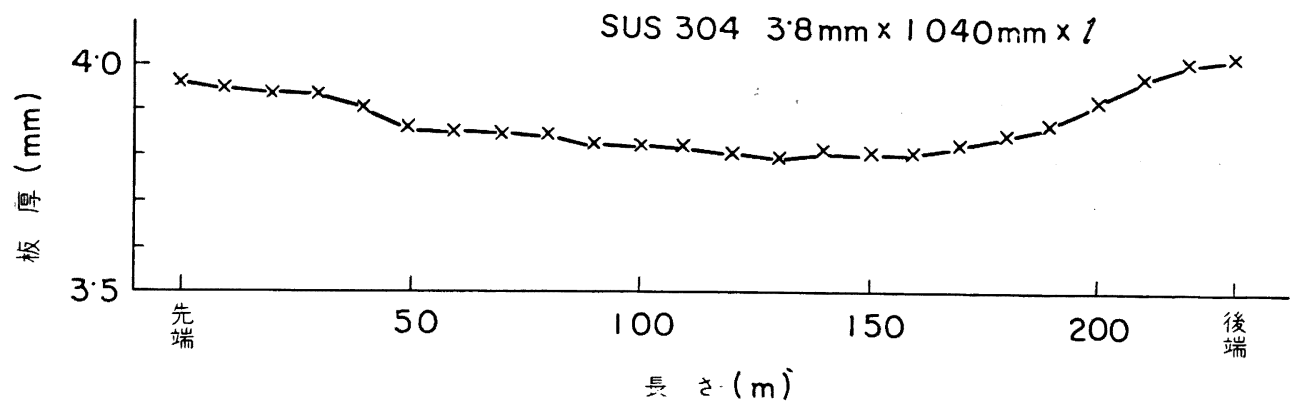

図 7 ステッケル压延機の長手方向の板厚変動

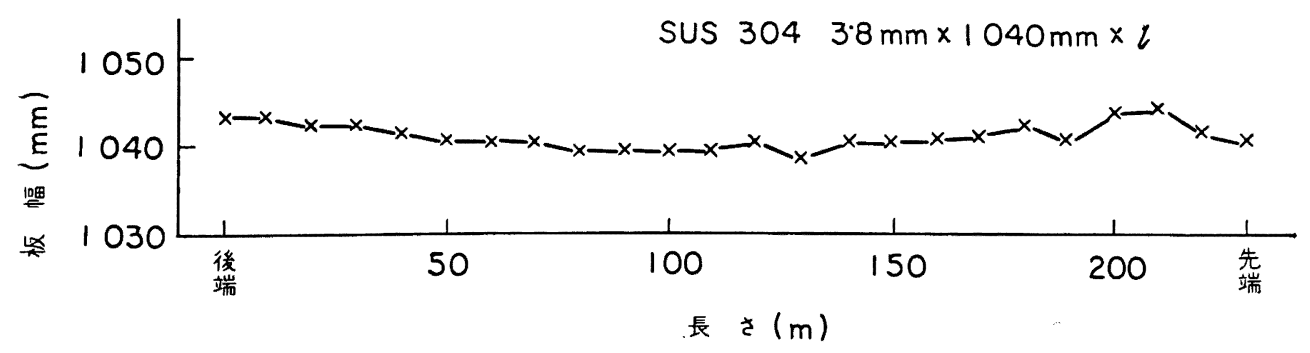

因 8 ステッケル圧延機の長手方向の板幅変動 
動が大であるまた，普通銅や特殊鋼を压延した場合， スケールの発生が多い.

品質向上のため，つぎに示すような改善が行なわれて いる.

（a）レバース圧延の際，頭部，尾部の放熱による温 度降下が著しいので, 正逆運転のアイドルタイム短縮の ための対策

（b）リールの回転開始時期を正確にするために，ス トリップの先端の通過をェアジェットで検出し，スロッ トまでの時間をタイマで調整するか，あるいは压延機と 連動した長さ計を用いている.

（c） ストリップのループを最小限におさえるため に，リールの加速および張力の電気制御を工夫している.

ステッケル圧延機の特徵はタンデム圧延機に比較し て，次の点があげられる。

（a）粗王延機と仕上王延機の 2 スタンドで設偖費が かからない。

（b）温度，圧下量などの調整範囲が広く，とくに， ステンレス鋼などに適している.

（c）圧延中に，ストリップの耳部が保温されるた め，よいエッジのストリップができる。

（d）製造コイル単重が 5〜7 $\mathrm{t}$ 程度の小量多品種の 生産に適している.

ステッケル圧延機は能力が 15000 20000 $\mathrm{t}$ 程度で, 中規模ステンレス鋼一貫工場の圧延機にふさわしく，最 もフレキシビリティに富んだ压延設備である.

(3) プラネタリ圧延機による圧延

プラネタリ圧延機は現在，実用化されているものに， センジミア式，プラッア式およびシングル式がある．現 在までに世界で設置稼動されたセンジミア式プラネタリ
圧延機を示すと表4のとおりである.

プラネタリ圧延機の圧延設備について， B 社の例の概 略を示すと図 9 のとおりである. また，プラネタリ圧延 機本体の構造を図 10 に示す.

プラネタリ圧延機はほかの圧延機と構造および圧延機 構が異なり，図 10 に示すように，大径のバックアップ ロールのまわりに多数の小径ワークロールを取りつけ, バックアップロールを駆動することにより，ワークロー ル群を公転および自転させて，ワークロールにより少し ずつ圧延するものである. したがつて，スラブはロール バイトを通過中に多数のワークロールにより，つぎつぎ に小さな圧下が加えられ，一回のパスにて $90 \%$ 以上の 圧下量を得ることができる。

プラネタリ圧延機のおもな特徽は次のとおりである.

(a) ロールバイトでの変形速度が大きく（70～140 $\left.\mathrm{sec}^{-1}\right)$, 压延中に発熱が起こるため，变形抵抗を小さく 保つて圧延することが可能である．したがつて，軟鋼か ら超合金鋼までのほとえどすべての鋼種のストリップ生 延ができる．その他，チタンなどの特殊金属の圧延にも 適している.

（b） スラブの加熱は通常の圧延機ほど高温にする必 要がないため，スケールの生成量が少ない上に，ロール バイトで形成するバックバンプによつて連続的にスケー ルが除去されるので, 表面品質のよいものが得られる.

(c) 炉抽出口からロールバイトまでの時間はスラブ のどの位置でも等しく，また，圧延機構造がプレストレ ス方式であるため，ストリップ全長にわたる板厚変動が きわめて少なく, 頭部, 尾部のオフゲージ部分はわずか である。

（d）タンデム圧延機に比較して，生産能力は高くな

表 4 センジミフ式プラネタリ压延設備一覧表

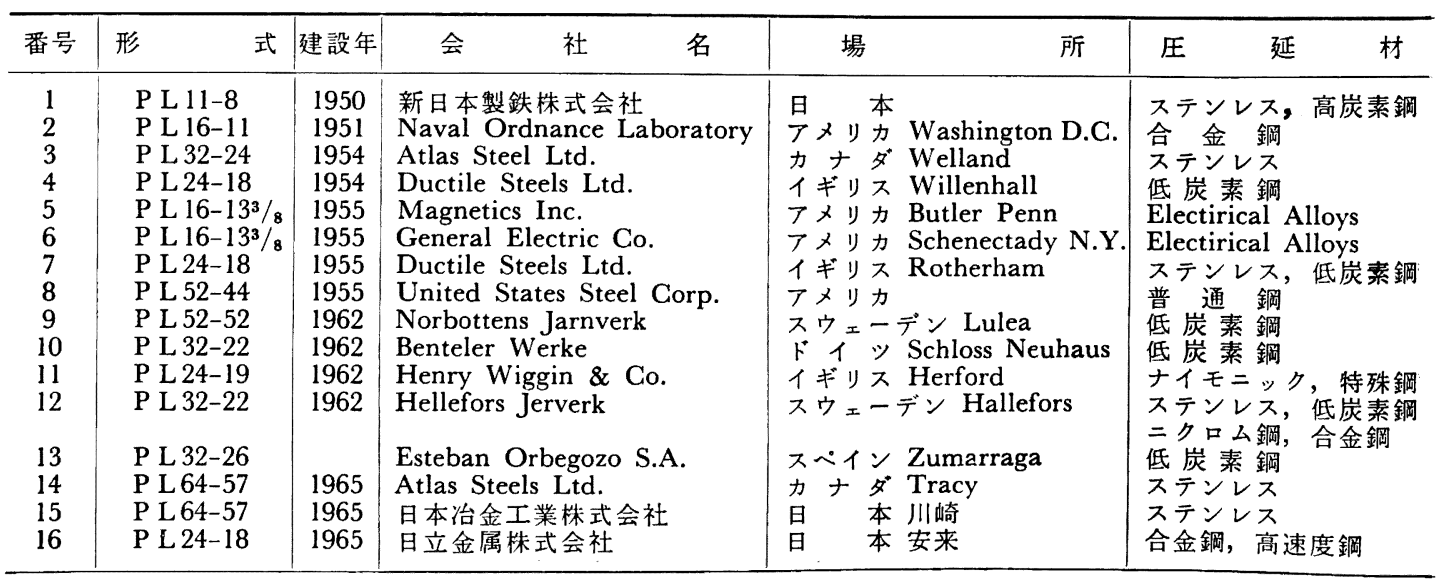




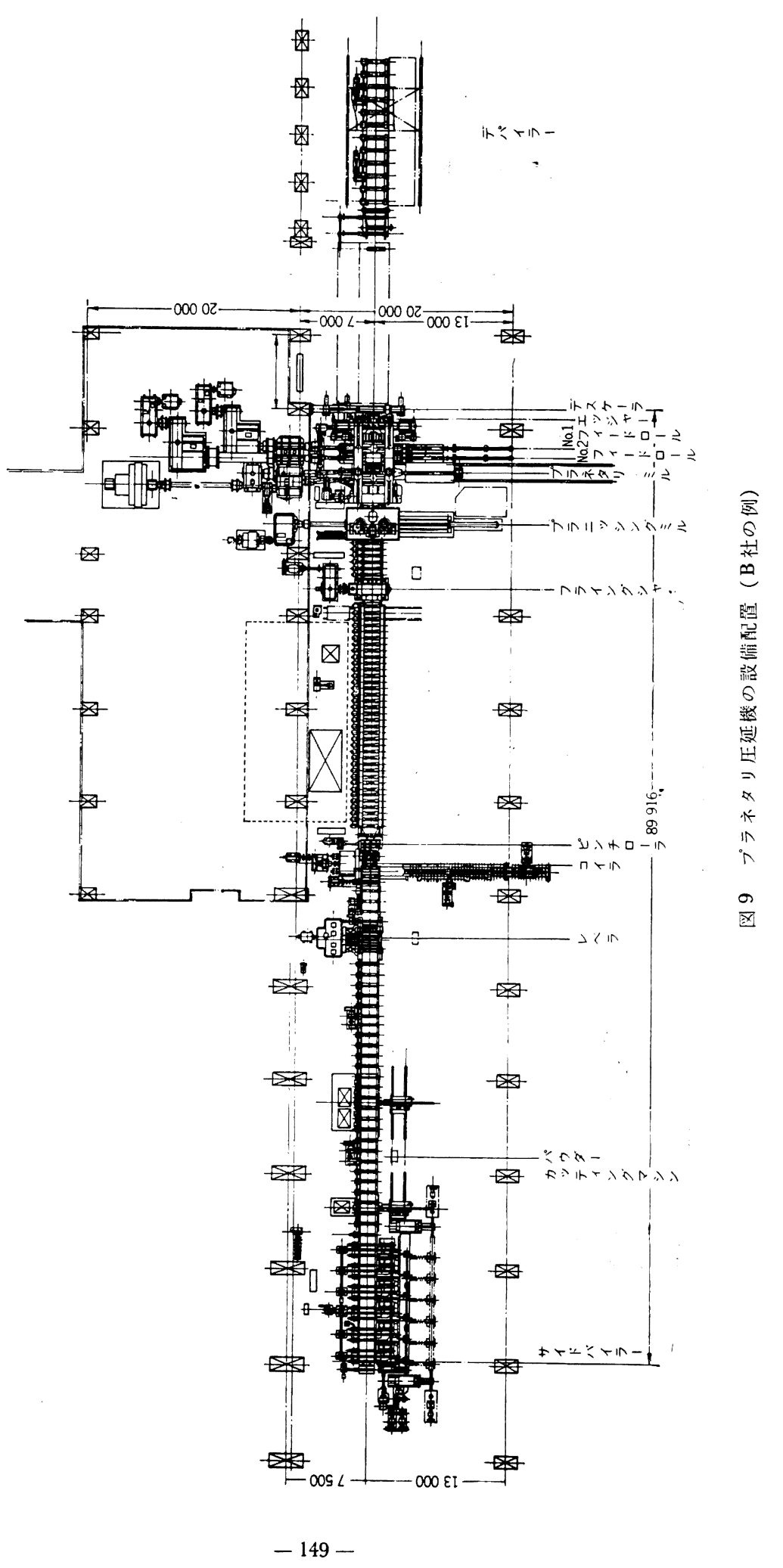




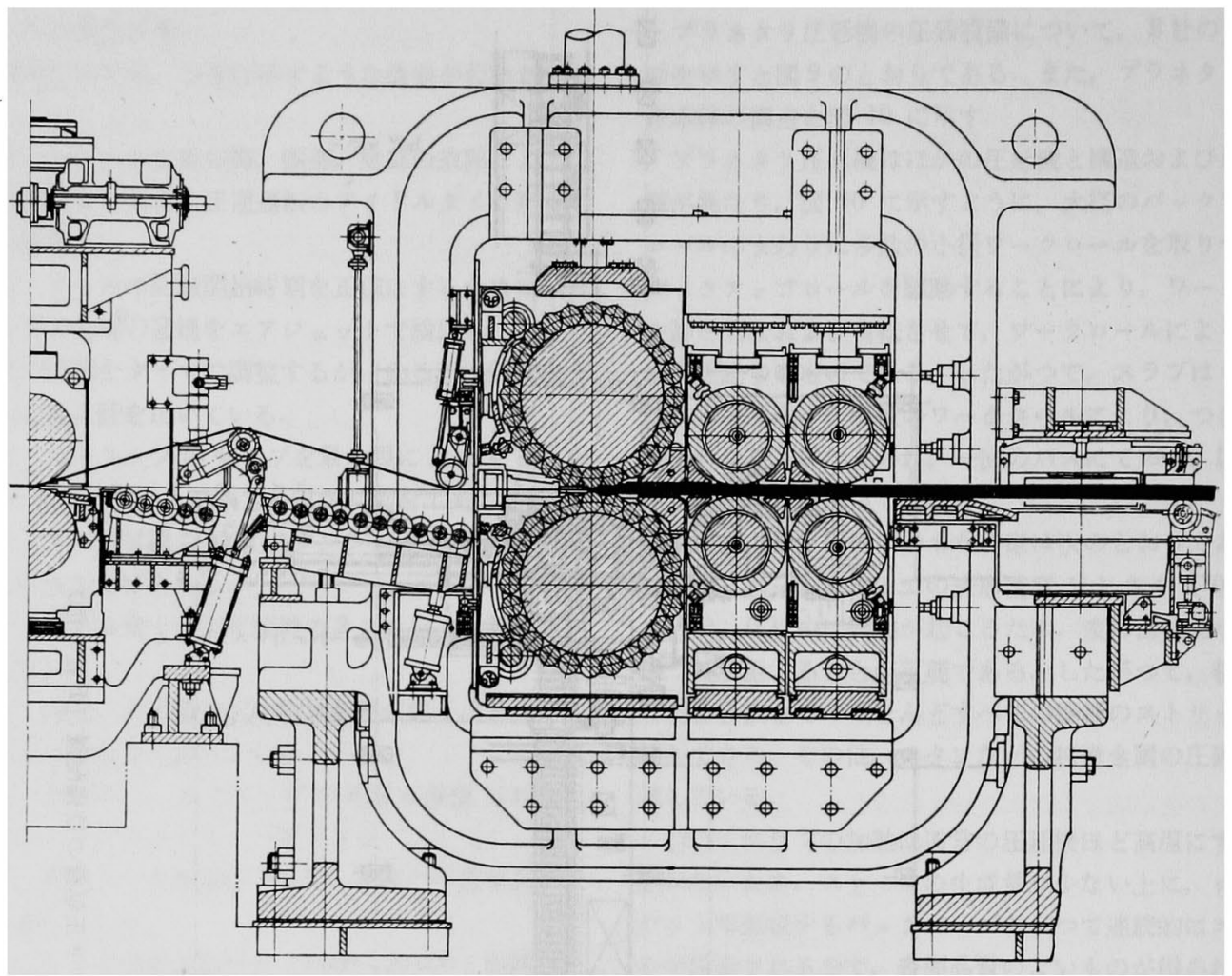

図10ブラネタリ圧延機の断面図

いがロールスタンドの数が少ないため, 圧延設備, 工場 敷地などの建設費が安く, とくに, 少量多品種の圧延に 適している.

（e）圧延中の振動および監音はほかの圧延機より大 きく，振動に対しては特殊な考虑を払う必要がある.

（f）通常の圧延機に比較して, エッジクラックの発 生が高い.

（g）圧延機の機構が複雑で操業およびメインテナン スに高度の技術を要し，ロール組替調整に時間がかか る.

プラネタリ压延機は表 4 に示すように，現在まで16台 が設置されており，圧延材料は普通銅から超合金鋼まで が対象となつているが，おもにステンレス鋼，合金鋼に 適用されている。

つぎに，最近設置された設備の主要㙨器について述べ る.

(i ) 加熱炉

加熱炉はプラネタリ压延機へのスラブの送り速度がき わめておそいため(約 $1 \sim 2 \mathrm{~m} / \mathrm{min}$ ), 炉から抽出したス ラブの温度降下を防ぐ目的で, きわめて圧延機に近接し

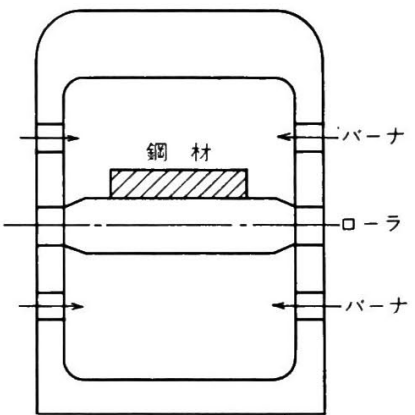

図11ローラハース式加熱炉

て設置され，ローラハース式加熱炉が用いられる．炉の 断面は図 11 のごとくで，炉長 $105 \mathrm{~m}$, 炉幅 $2680 \mathrm{~mm}$ で, 長さ $6500 \mathrm{~mm}$ のスラブを $1 \mathrm{t} / \mathrm{m}^{2} \cdot \mathrm{hr}$ の炉床負荷, $135 \mathrm{t} / \mathrm{hr}$ の加熱能力を有している. 加熱炉の熱源として は重油とガスの併用である.

(ii) デスケーリング装置

スケールのロールバイトヘのくい込みを防止するため に，炉出口とエッジャとの間に本装置が 設けられてい 
る. 機構としては $140 \mathrm{~kg} / \mathrm{cm}^{2}$ 程度の高圧水噴射ノズル をスラブの直角方向に往復動作させるようになつてい る.ステンレス鋼の圧延ではスケールの発生が少ないた め, その使用は必要条件ではない.

(iii) エッジャ

プラネタリ在延機入口に近接して配置され，これでス ラブ幅方向にわずかに圧下を加える．耳割れを極力少な くするために，ロールはRをつけている、しかしながら 板のエッジの形状は数 mmのV溝がある.

(iv) プラネタリ压延機

プラネタリ圧延機は図10 亿示すとおり，2組のフィ ードロールと一組のプラネタリロールから構成されてい る. フィードロールは圧延機のロールバィトにおいて, バックスラストに打ち勝つてスラブをロールバイトに連 続に，一定速度で送り込むためで， No 1，2 のフィー ドロールでおのおの 10〜30\% の圧下が加えられる.

プラネタリロールは一対のバックアップロールのまわ りに多数のワークロールを公転させスラブを圧延する. 各ワークロールはバックアップロー北と同軸に組み込ま れたケージによつて支持され，ケージ内に組み込まれた ワークロールチョックおよびスプリングアセンブリによ り遠心力に打ち勝つ力でバックアップロールに押し付け られている.ケージはシャフトおよびギヤにより，水平 および垂直方向に同調してバックアップロールのまわり を回転する機構になつている。すなわち，上下一対のワ ークロールはまつたく同時にロールバイト内の垂直中心 線を通過するとともに，水平方向に対してはワークロー ルとバックアップロール軸がつねに平行であるように同 調機構により調整できる構造になつている.

圧延中に発生する $30 \sim 35 \mathrm{~Hz}$ の振動と圧延圧力および バックスラストの急激な変動に対して， $350 \mathrm{~kg} / \mathrm{cm}^{2}$ の 高圧シリンダによるプレストレス方式, ソールプレート 下面の弾性パットの工夫などでこの振動を吸収するよう 設計されている.このプレストレス方式は圧延機の剛性 を増し, 板厚精度を高め, かつ振動を吸収し, さらには 八ウジングの断面積および重量を低減できる特徵をもつ ている.

ゲーシ調整は上下バックアップロールのチョック間に ウェッジが設けられ，これを摺動することにより圧延中 のゲージ変更も可能な構造になつている.

因 12 にロールバイトの原理を示す. ワークロールお よびヶージはバックアップロールとスラブ間の摩擦によ り駆動される機構になつている. ワークロールがスラブ の進出方向と逆に回転しているため，スラブをロールバ イトに引き込む力は発生しない.このため,フィードロ

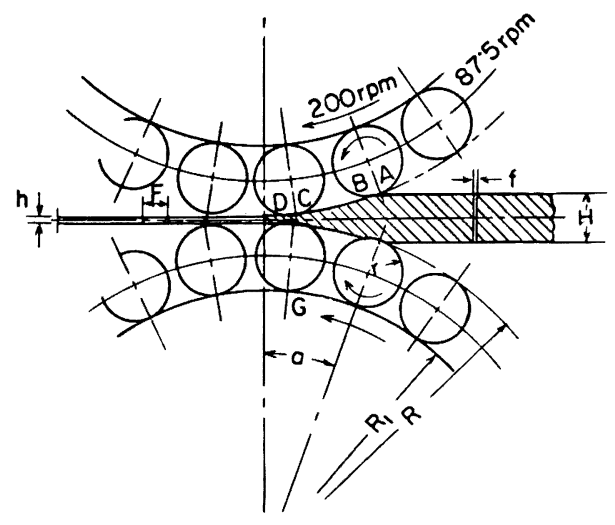

因12ロールパイトの原理

ールによつて，一定の速度で連続的にスラブの押し込み を行なわなければならない，また，ワークロールは常 に, 被压延材に 1 ～ 2 本コンタクトしていなければケー ジの回転が不安定となるので入側スラブ厚さは出側厚さ に対して 18〜24 倍程度必要である.

（v） プラニッシング压延機

プラネタリ圧延機およびコイラ巻取りに適当な張力を 与え，かつ，プラネタリ圧延機特有のスキャロップマー クをわずかな圧下で平担にするためにプラニッシング 圧延機を設置している．圧下率は 5〜10\% 程度である。 この圧延機で圧延された板ではスキャロップによる厚み の差は $\pm 0.01 \mathrm{~mm}$ 以下で 30 50\% の冷間圧延で視覚 的にも完全に消えている．また，圧延機構から起こるス トリップ尾部の厚肉部がこの圧延機を通過するときに発 生する過負荷を逃げ，後続ストリップの頭部の通過を容 易にするためのロールクイックオープン機構を取り入れ ている.

各種プラネタリ圧延機のスラブおよび製品寸法の例を あげると次のとおりである.

(a) PL64-57 の例

材料：ステンレス鋼, その他

スラブ寸法：最大 $140 \times 1300 \times 6500 \mathrm{~mm}$

スラブ重量：最大 $7800 \mathrm{~kg}$

ストリップ: $3 \cdot 5 \sim 6 \mathrm{~mm}$ 厚

シ - : $6 \sim 25 \mathrm{~mm}$ 厚

プレート: 25〜 $50 \mathrm{~mm}$ 厚

(b) PL24-18 の例

材料：合金工具鋼，高速度鋼，ステンレス鋼 スラブ寸法：最大 $49 \times 380 \times 5000 \mathrm{~mm}$

スラブ重量 : 最大 $750 \mathrm{~kg}$

ストリップ : 1.5〜 $6 \mathrm{~mm}$ 厚 


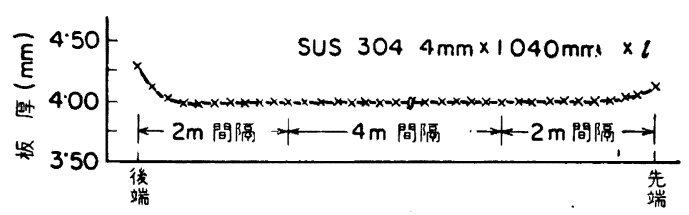

困13 プラネタリ压延機の長手方向の板厚変動

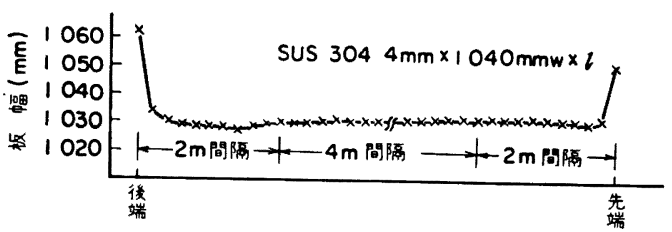

四14 プラネタリ压延㙨の長手方向の板幅变動

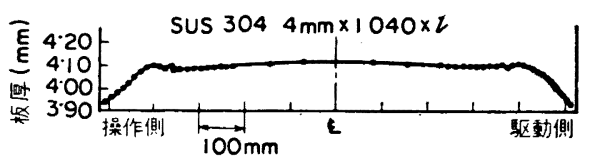

(a)

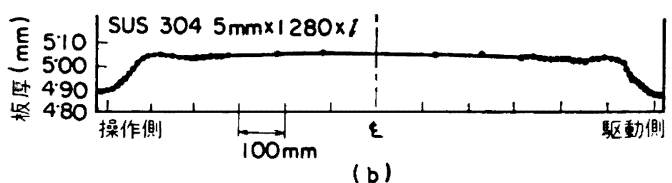

図15プラネタリ压延機の幅方向の板厚変動

また，PL64-57 で圧延された製品の板厚および板幅 の一例を示すと図 13, 図14および図 15 の通りである.

ストリップ長手方向の板厚の変化は頭部, 尾部それぞ れ 7〜10m を除いて, 中央部は非常に安定している，ま た，板幅も板厚と同様，両端の不安定部を除いて，その バラッキは非常に少ない. 板厚の頭部，尾部における変 動はプラネタリ圧延機とプラニッシング圧延機間の無張 カとストリップェンドの折れ曲りをさけるためのプラニ ッシングロールのクイックオープンが原因となつてい る. 板幅方向の変化は図 15 のごとく，耳部がドロップ している.

ストリップの表面肌はプラネタリ圧延機の特徵で述べ たごとく，スケールの発生が少なく，きわめて良好なも のが得られ，タンデム圧延機と同程度の水準である.

本設備の能力は最大 5 万 $\mathrm{t}$ 程度が可能と推定され, 連 鋳スラブとの組合わせでコイルの大型化が容易な圧延機 である.

\section{4. 冷間 圧延}

冷延技術の進歩についてみると, 品質, 能率, 原価面 において製造工程全搬にわたつてみられるが，その顕著
なものについてつぎに述べる.

冷間圧延は，特殊鋼, 㳄鋼, 珪素鋼などと大差なく，圧 延機の型式としては多段式のセンジミア圧延機，4段レ バーシング压延機, 幅狭用として多段のローン圧延機な ぞがあり，実作業においては，それぞれの特徵を生かし た作業がなされているが，ステンレス鋼のように加工硬 化の大きい材料を能率良くしかも厚み精度良く圧延する には, 径の細いワークロールと圧延機の剛性が重要な要 素であり，この点でセンジミア圧延機が最も適している ものといえる.

表 5 に国内各社に設置されているステンレス鋼用のセ ンジミア圧延機の状況を示す.

\section{$4 \cdot 1$ 冷間压延梂の進歩}

当初わが国に導入された広幅センジミア圧延機は，4 フィート幅圧延機であり，圧延機仕様の一例は次のとお りである.

コイル重量 $\quad: 8 \mathrm{t}$

$\begin{array}{lll}\text { 幅 } & \text { : 最大 } & 1240 \mathrm{~mm} \\ \text { コイル外径 } & : & 1100 \mathrm{~mm} \\ \text { コイル内径 } & : & 510 \mathrm{~mm}\end{array}$

標準ワークロール径 : $54 \phi$

ミルモーター ：1400吕

巻取機用モーター : $1200 \mathrm{P}$

压延速度 : 最大 $200 \mathrm{~m} / \mathrm{min}$

巻取張力 : 最大 $22.5 \mathrm{t}$

その後, 生産量の増大とともに, 圧延機の高速化，大 型化の構想が持たれている折，溶接工数の低減を主目的 に, 化学プラント用材として広幅鋼板の要求が出されて きたこともあつて, 昭和 46 年以降 5 フィート幅圧延機 が設置され始め，現在国内で 5 基が設置されている.そ の仕様を表 6 に示す.

5 フィート幅圧延機の特徵として次の点が挙げられ る.

（a）コイル単重の増加

(b) 圧延速度の増加

(c) 巻取張力の増大

(d) ワークロール径の増大

コイル単重については最大 $27 \mathrm{t}$ のものもあり, 幅の 増加と相まつて設備が非常に大型化した.このコイル単 重増によりコイル長さが長くなつた結果, 圧延速度増は ますます意味のあるものとなり，そのため，ストレート ミネラルオイルより冷却性能が優れた，ソリブルオイル を使つて，最大圧延速度 $500 \mathrm{~m} / \mathrm{min}$ の圧延機も現われ た.

当初の圧延機の巻取り機は，コラプシブルマンドレル 
表 5 国内のステンレス鋼用広幅センジミア圧延機一臨表

\begin{tabular}{|c|c|c|c|c|c|c|}
\hline 型 & 建 設 年 & 社 & 所 & 在 地 & 考 & 速度 $\mathrm{F} / \mathrm{min}$ \\
\hline $\begin{array}{l}\text { Z R 22-50 } \\
\text { Z R 22-50 } \\
\text { Z R 21 A-62 } \\
\text { Z R 22-50 } \\
\text { Z R 22-50 } \\
\text { Z R 21 B-62 } \\
\text { Z R 22-50 } \\
\text { Z S 07-75 } \\
\text { Z R 22 B-50 } \\
\text { Z R 21 B-62 } \\
\text { Z R 22-50 } \\
\text { Z R 22-50 } \\
\text { Z R 22N-50 } \\
\text { Z R 21 B -50 } \\
\quad " 1 \\
\quad \text { " } \\
\text { Z R 22-50 } \\
\text { Z S 07-60 } \\
\text { Z R 22-50 } \\
\text { Z R 21 B -62 } \\
\text { Z R 22-50 } \\
\text { Z R 22-50 } \\
\text { Z R 21 B -63 }\end{array}$ & $\begin{array}{l}1962 \\
1968 \\
1971 \\
1960 \\
1970 \\
1972 \\
1962 \\
1966 \\
1969 \\
1971 \\
1958 \\
1964 \\
1969 \\
" 1 \\
" 1 \\
1959 \\
" 1 \\
1964 \\
1971 \\
1964 \\
1968 \\
1972\end{array}$ & 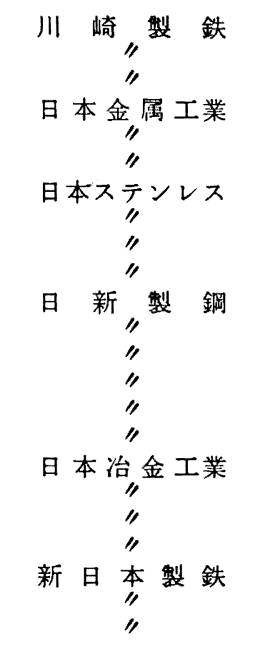 & $\begin{array}{l}\text { 西 } \\
\text { 相 } \\
\text { 衣 } \\
\text { 直 } \\
\text { 鹿 } \\
\text { 周 } \\
\text { 川 }\end{array}$ & $\begin{array}{l}\text { "宮 } \\
\text { " } \\
\text { 模 原 } \\
\text { " 浦 } \\
\text { 江 津 } \\
\text { " 島 } \\
\text { " 南 } \\
\text { " } \\
\text { " } \\
\text { " } \\
\text { " } \\
\text { " 崎 } \\
\text { " } \\
\text { 光 } \\
\text { " }\end{array}$ & $\begin{array}{c}\text { シート圧延機 } \\
\text { タンデム压延機 } \\
\text { "' } \\
\text { " } \\
\text { シート压延機 }\end{array}$ & $\begin{array}{r}750 \\
1150 \\
1000 \\
900 \\
900 \\
1200 \\
625 \\
242 \\
1310 \\
1150 \\
790 \\
1200 \\
1000 \\
1320 \\
1640 \\
1970 \\
650 \\
250 \\
656 \\
1475 \\
750 \\
1150 \\
1510\end{array}$ \\
\hline
\end{tabular}

表 6 国内各社の 5 フィート幅センジミフ圧延機の状況

\begin{tabular}{|c|c|c|c|c|c|}
\hline 項目会社名 & 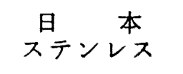 & 新 & 川 & 日本金属工業 & 日本治金工業 \\
\hline $\begin{array}{c}\text { 圧延材型式 } \\
\text { max ユイ重量 }(\mathrm{kg}) \\
\text { 最大 幅 }(\mathrm{mm}) \\
\text { 最小幅 }(\mathrm{mm}) \\
\text { 圧延速度 }(\mathrm{m} / \mathrm{min}) \\
\text { 原 み 計 } \\
\text { A G C } \\
\text { 潤 滑 油 } \\
\text { フィルター } \\
\text { 巻取 機 } \\
\text { ドラムタイプ } \\
\text { ドラム径 ( } \mathrm{mm}) \\
\text { 最大張力 }\end{array}$ & $\begin{array}{c}\text { Z R21 B-62 } \\
20000 \\
1600 \\
914 \\
250 / 350 \\
\text { X-Ray } \\
\text { なし } \\
\text { ストレート } \\
\text { ミネラル } \\
\text { スンシック } \\
\text { コラプシブル } \\
\text { マントレレル } \\
610 \\
45000 \mathrm{~kg} \\
(350 \mathrm{~m} / \mathrm{min})\end{array}$ & $\begin{array}{l}\text { Z R21 B-63 } \\
27000 \\
1600 \\
914 \\
250 / 500 \\
\text { X-Ray } \\
\text { あり } \\
\text { ソリプル } \\
\text { ホフマン } \\
\text { " } \\
660 \\
50000 \\
(350)\end{array}$ & $\begin{array}{c}\text { Z R21A-62 } \\
15000 \\
1580 \\
950 \\
125 / 300 \\
\gamma-\mathrm{Ray} \\
\text { フライシグ } \\
\text { マイクロメータ- } \\
\text { あり } \\
\text { ストレート } \\
\text { ミネラル } \\
\text { スペック } \\
\\
\text { ソリッドタイプ } \\
660 \\
60000 \\
(225)\end{array}$ & $\begin{array}{c}\text { Z R21 B-62 } \\
20000 \\
1580 \\
940 \\
200 / 400 \\
\text { X-Ray } \\
\text { あり } \\
" 1 \\
\text { スパミック } \\
\text { コラ゚シプル } \\
\text { マンドレル } \\
610 \\
45000 \\
(340)\end{array}$ & $\begin{array}{c}\text { Z R } 21 \text { B }-62 \\
15000 \\
1580 \\
940 \\
260 / 450 \\
\text { X-Ray } \\
\text { フライング } \\
\text { マイクロメーター } \\
\text { あり } \\
\text { " } \\
\text { カートリッチ } \\
\text { " } \\
610 \\
45000 \\
(360)\end{array}$ \\
\hline
\end{tabular}

タイプで, 径は $510 \mathrm{~mm} \phi$ が標準であつたが，その後圧 延時の帯鋼の形状確保と圧延能率向上のために張力増を 図り，ドラム強度の高いソリッドブロックマンドレルタ イプが作られ径も $610 \mathrm{~mm} \phi$ が標準である.ソリッドブ ロックマンドレルタイプは, 压延時の層間スリップが少 ないという利点があるが，このタイプは巻き戻しのため の設備（リワインダー）が必要であり，またハンドリン グ時間が若千長くなる.

5 フィート幅圧延機では, 従来よりも大幅な張力増と なつているが，マンドレル径を大きくして，強度增がな された結果，コラプシブルマンドレルタイプが使用され

\section{ている例が多い.}

圧延速度の增大により，ワークロールの泠却対策を強 める必要があり，また，コイル長さが長くなることと大 型化による強圧下のため，ロール摩耗対策をとる必要が あり, ワークロール径は当初の標準径 $54 \mathrm{~mm} \phi$ より標 準径 $86 \mathrm{~mm} \phi$ 人と大きくなつた. このことはまた，5 フィート幅圧延機で压延された成品の形状改善も寄与し ている.

なお，ワークロールの交換は従来作業者の手作業によ つていたが，ロール径が大きくなり，長さも長くなるこ とによりロール交換装置が使われだした. 


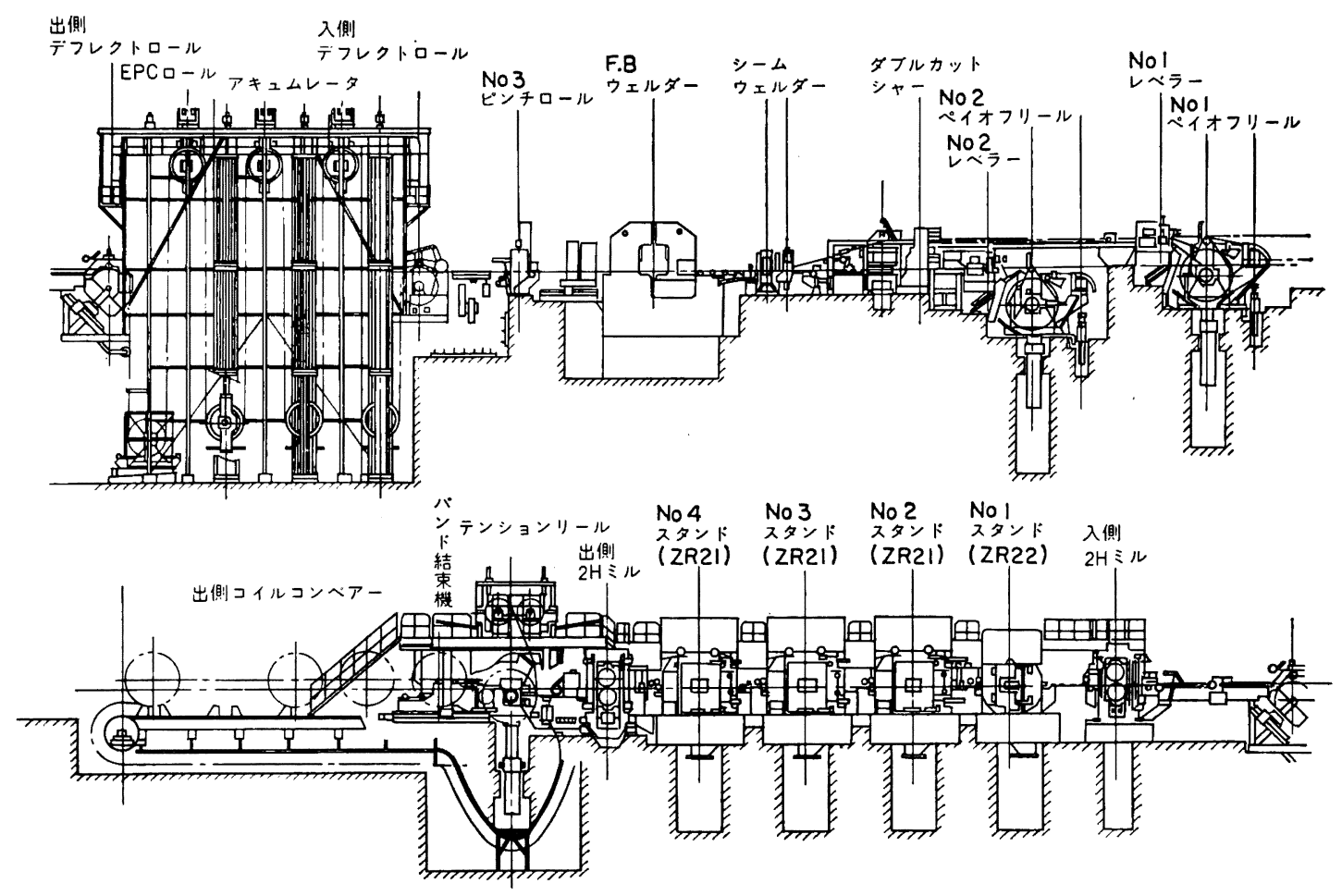

因16 センジミフコールドタンデム压延機全体配置図

一方，ステンレス鋼を普通鋼なみの生産方式によつて 大量生産し，コスト低減を図ろうという目的でセンジう ア圧延機のタンデム化が因られ，昭和 44 年より稼働し ている.

この全体配置図を図 16 に示す.

センジミア压延機のタンデム化は, 一般の 4 段圧延機 のタンデム圧延機と異なる問題がある.

すなわち，小径ロールゆえにストリップのロールヘの かみ込みが困難であり，あらかじめロールギャップを正 確に設定して通板することも難しく，またバックアップ 駆動のタンデム圧延機も例が少ないので，ロールスリッ プも想念された.

このコイル 先端のかみ込み性の問題に対処するため に, 入側に溶接機を設置し, 先行コイルの後端と後行コ イルの先端を溶接し, 連続して通板する方法がとられて いる. 溶接の際, もし圧延が停止すると，各スタンドで 板にロールストップマークが発生するが，これを防止す るため溶接機と圧延スタンド間にループタワーを設けて いる.

したがつて，センジミア圧延機のタンデム圧延機化に おいては，溶接技術が非常に重要となり，溶接技術の向
上が図られた. その結果溶接部の強度はオーステナイト 系は勿論のこと, フェライト系ステンレス鋼でも, 満足 できる結果が得られている. このフェライト系ステンレ ス鋼に対する溶接技術の進歩が，タンデム化を可能にし たものといえる.なお, 溶接部圧延時, 溶接部の破断を 防ぐ装置として, 下部圧下機構中に, 従来の定位ロック 機構のほかに, 定圧圧下機構, 定量開閉機構が付け加え られている・

入，出両側には大径の 2 段圧延機を設置して，大きな 張力を負荷して, スリップ防止, 形状確保, 圧下率増大, 運転の安定化をはかつている. 出側の 2 段圧延機の設置 は同時に, テンションリールの負荷を軽減させている.

圧延速度は最大 $600 \mathrm{~m} / \mathrm{min}$ で, このため, 圧延油と しては水溶性油を使用し，バッキングベアリングへの潤 滑は, 別系統のオイルミスト装置により行なわれてい る.

\section{2 压延機周辺技術の進歩}

(1) ワークロール

ワークロールは, 従来高炭素高クローム鋼ロールが使 用されていたが，需要家よりの表面光沢およびバフ性の 要求が㛜しくなるにしたがい, 耐摩耗性, 圧縮強度にす 
ぐれた, 表面硬度の高いタングステンカーバイド燒結口 ールも使用されるようになつた.

しかし，タングステンカーバイド焼結ロールは蜮性に 欠け，ピンホール状の欠陥が出やすく，高価で，さらに 研削性が劣り，比重が高いために取り扱いにくいという ことで，ごく一部しか使われていない.

しかし最近の圧延機の大型化, 高度化によるロール使 用条件の封酷さと表面品質に対する厳しい要求からワー クロールの品質改喜がさしせまつたものとなつている.

このためロールメーカーは, 原料粉末の品質やプレス 技術ならびに真空焼結技術などの向上より，タングステ ンカーバイトロールの改善に努力する一方, タングステ ンカーバイトロールに代わるものとして高炭素高バナシ ウム高速度鋼ロールの開発を行なつている. 高炭素高バ ナジウム高速度鋼ロールは, 高炭素高クロム鋼ロールと 比較して, ロールの表面仕上度, 耐摩耗性, 耐事故性の すぐれたものとして認められ，とくに良好な成品表面品 質が得られるロールとして, 最近使用される割合が高 い.しかしながら, 研削性は工具鋼と比較すると劣り, 研削時に炭化物が脱落してロール表面にピット状の矢陥 が出る㦟念があり, さらにロールメーカーでの改良が必 要とされている.

各種ロールの一般的な成分と硬度を表 7 に示す.

(2) 圧延油

圧延油は，ストレートミネラルオイルが大部分を占め ており, 従来ナフテン系の粘度, SSU $100\left(100^{\circ} \mathrm{F}\right)$ 程 度の油が主体であつたが, 最近では, 粘度指数が高く, 高圧粘度がナフテン系より小さく, 高圧下での潤滑性が 良好であるパラフィン系の SSU 80 程度の油が多く使用 されるようになつた. さらに SSU 60 程度の低粘度油も 使われており，このことが表面光揮度の向上に大いに寄 与している.
現在，ストレートミネラルオイルが使われる筙囲は， 圧延速度がほほ $400 \mathrm{~m} / \mathrm{min}$ 以下の圧延機であり, それ 以上の压延速度ではソリブルオイルが使われている. ソ リブルオイルは，潤骬性能は，ストレートミネラルオイ ルより若千劣るが，冷却性能は，約 2 倍の効果が期待で きる.ちなみにミルモーター出力に対する圧延油量は， 標準的にストレートミネラルオイル約 $3.2 \mathrm{l} / \mathrm{min} / \mathrm{kW}$, ソリブルオイルでは約 $1.6 \mathrm{l} / \mathrm{min} / \mathrm{kW}$ といわれている.

圧延油の汇過方法は，ストレートミネラルオイルにつ いては，当初バッグフィルター，カートリッジフィル夕 一などが使われており，沪過精度の向上のため沪材の改 良が進められていた，その後，沪過性能にすぐれ，また 全自動化された沪過方法として, 珪藻土使用のプレコー トフィルターが考案され，さらに最近では，安定して高 沪過精度を期待できるリング状のグラスウール成形品に よるスパミックフィルターが開発されるにいたつて，圧 延油の清浄度はますます向上してきた. しかしスパミッ クフィルターは，設置のために相当広いスペースを必要 とする欠点がある.したがつて最近の汇材の改良と相ま つて，カートリッジ方式もまだまだ捨てがたい面もあ る. またスパミックフィルターは, 現在圧延油添加物の 捕捉の点で調査が進められている。

ソリブルオイルについては, フラットベッドタイプの ハイドロメーションフィルターが使用されている.

(3) 厚み制御

近年厚み精度の要求も一段と厳しくなり, 種々の電気 制御のもとに AGC が設置され始めた． 従来の圧下制御 はフォローバルブ・システムによつて行なわれており, 応答速度がが遅く，AGC の効果を十分に生かしえなか つたが，最近になつて米国で応答速度の速いエレクトロ ハイドロリックサーボバルブシステムが開発され，コン ピュータとの組合わせでフィードフォワードコントロー

表 7 各種ワークロールの成分と硬度

\begin{tabular}{|c|c|c|c|c|c|c|c|c|c|c|c|c|}
\hline 項 目 & \multicolumn{11}{|c|}{ 成 } & \multirow{2}{*}{$\stackrel{\text { 硬 }}{(シ ョ ア \text { 度 }}$} \\
\hline 材質 & C & $\mathrm{Si}$ & $\mathrm{Mn}$ & $\mathbf{P}$ & $\mathrm{S}$ & $\mathrm{Cu}$ & $\mathrm{Cr}$ & Mo & W & V & Co & \\
\hline $\begin{array}{l}\text { 高 炭 素 } \\
\text { 高クロ鋼 }\end{array}$ & $\underset{1 \cdot 70}{\stackrel{1 \cdot 30}{\sim}}$ & $\begin{array}{l}0.15 \\
0.50\end{array}$ & $\begin{array}{l}0.15 \\
0.50\end{array}$ & $<0.030$ & $<0.020$ & $<0 \cdot 20$ & $\frac{10 \cdot 15}{\widetilde{13} \cdot 5}$ & $\begin{array}{c}0.60 \\
1 \cdot 20\end{array}$ & & $\begin{array}{c}0.20 \\
0.90\end{array}$ & & $83 \sim 88$ \\
\hline \multirow{2}{*}{$\begin{array}{l}\text { 高岸素高バナジ } \\
\text { ウム高速度鋼 }\end{array}$} & $1 \cdot 55$ & & & & & & $4 \cdot 75$ & $3 \cdot 00$ & $6 \cdot 50$ & $5 \cdot 00$ & $5 \cdot 00$ & \multirow{2}{*}{90 以上 } \\
\hline & $1 \cdot 48$ & & & & & & $5 \cdot 41$ & $4 \cdot 40$ & $5 \cdot 05$ & $4 \cdot 74$ & $4 \cdot 86$ & \\
\hline $\begin{array}{r}\text { *ングステン } \\
\text { カーパイト }\end{array}$ & $\stackrel{4}{\sim 6}$ & & & & & & & & $\begin{array}{l}83 \\
\sim 87\end{array}$ & & $\begin{array}{l}8 \\
\sim 11\end{array}$ & $\begin{array}{l}\text { ロックウエ } \\
\text { ル } 90\end{array}$ \\
\hline
\end{tabular}


ルすることにより，良好な厚み精度を得られる AGC シ ステムが開発され，国内にも導入されている.

これは, 入側の厚み計によつて, 所定板厚に対する偏 差を測定し，一定間隔でコンピューターのメモリーに記 憶させ，一方パルスカウンターにより材料の走つた長さ を测定し，入側厚み計で測定された位置が，ロールバイ 卜に差しかかる位置を検出し、メモリーより厚さの偏差 をひきだし，出側所定板厚に対して演算し出側材料の長 さを求め, この長さに圧延するように, 圧下制御系に 1 秒間に数 10 回の指示を与えるむのである.

したがつて制御精度に影響を与えるものは
(a) 板厚測定精度
(b) 単位長さ当りのゲージ補正頻度
（c）演算の精度
（d）圧下系の精度

などであり, とくに圧下系の精度は, 従来のフォローバ ルブでは, 約 $600 \mathrm{~m} / \mathrm{sec}$ の応答時間といわれているので これは $600 \mathrm{~m} / \mathrm{min}$ で走つているときには, $6 \mathrm{~m}$ の長さ に相当する.エレクトロ八イドロリックサーボバルブで は, 応答時間約 $30 \mathrm{~m} / \mathrm{sec}$ Łいわれており, AGC シス テムの効率化に結び付き, 仕上り板厚精度で $12.5 \mu$ 以 内を容易に得るといわれている.

\section{$4 \cdot 3$ 今後の問題点}

圧延機としてはセンジミア压延機が定着し, 大型化も かなり進んでいるといえる.

今後はむしろ品質面に重点が移行し, 次のような周辺 技術の改良が行なわれて行くであるう.

（a）高精度 AGC システムの利用による厚み精度の 向上

（b）ロール材質, 研削方法の改善および低粘度で, 極圧に耐える圧延油の開発による成品表面光沢の向上

(c) 表面疵検出機の有効利用による能率歩留の向上 (d) 省力化

\section{4 焼鈍}

冷間圧延機の進歩とともに, 生産規模の大型化が進 み, 焼鈍工程においても高能率が要請され, それに対処 するため焼鈍方式における設備および技術面の研究開発 が行なわれてきた．以下に最近開発実用化されたものを 含めて代表例を紹介する.

（1）連続焼鈍設備の進歩

ステンレス鋼带の焼鈍設備は加熱方式で分類すると, 開放雾囲気中で行なう直火式加熱焼鈍炉と, 無酸化性雲 囲気で加熱を行なう光輝焼鈍炉とに大別される. さらに 炉体構造上から直火式焼鈍炉はカテナリー炉と堅形炉に 分類できる.
直火式焼鈍炉はほとえどカテナリ一炉方式で占められ ており，最近になつて竪形炉方式が開発されたがまだそ の稼動実施例は少ない、したがつて直火式焼鈍炉の開発 進歩はカテナリ一炉とともに進められたが，その達成の ためにはつぎにあげる関連技術の進歩が大きく寄与して いる.
(a) 計測制御
(b) 加熱バーナー
(c) 耐火断熱材
(d) ライン通板速度制御

従来のカテナリー炬においては焼鈍目標温度に炉温を 設定し，材料がその目標温度に昇温するために必要な時 間が有効在炉時間となるようにラインスピードを設定し た通常加熱法がとられていた. 近年は焼鈍目標温度に対 して炉温を $50^{\circ} \mathrm{C} \sim 200^{\circ} \mathrm{C}$ 高く設定し, 材料が目標温度 に到達後, 直ちに抽出し, 冷却されるようにラインスピ 一ドを設定した急速加熱法が行なわれている.

通常加熱法では, 炬壁の輻射および燃焼ガスの対流熱 伝達が主要加熱源となつているが，急速加熱の進えだ段 階では燃焼高温ガスを直接材料に噴射する衝撃加熱など の高速加熱法も採用されている. カテナリ一炉で高い通 板能力を得るには，有効炉長を長くする必要がある。し かし，高温に加熱された状態の材料ではカテナリ一垂下 量および, 炉内張力の設計に限界があり，それを補うた めには支持ロールが増光，炉の多分割が余儀なくされ る. 炬が分割される支持ロール部では材料の加熱が停止 されるだけでなく，侵入空気による冷却によつて加熱奻 率の低下を引き起こすことになる．侵入空気による冷却 防止の対策として, 炉外板を一体炉構造として炉分割部 を外気から隔凯し, 支持ロールはサイドからの差し込み 方式とする構造によつて熱効率の向上をはかつたカテナ リー焼鈍炉も稼㗢している

また，燃焼ガスの対流伝達による加熱は，燃焼ガスの 流れを材料の通板方向に対して逆方向にとつた方が効率 が高く, 従来排気煙道を炉の入口出口双方に設置してい たものを，入口側だけとした炬構造も実用化されている (図17参照).

カテナリー炉において，熱効率の向上および急速加熱 化を進めてゆく場合, 支持ロールがより高温にさらされ るため，一層優れた耐高温性支持ロールが必要となり， 押し込み疵など表面疵の発生トラブルが，大きな問題と なるカテナリー炉で課題となつた炉の一体化，熱勃率の 向上, 支持ロールによるトラブルの防止などの対策とし て竪形焼鈍炉が1968年に開発された・堅形炉の実用化に 当つては, カテナリー炉での進歩に加えていくつかの新 


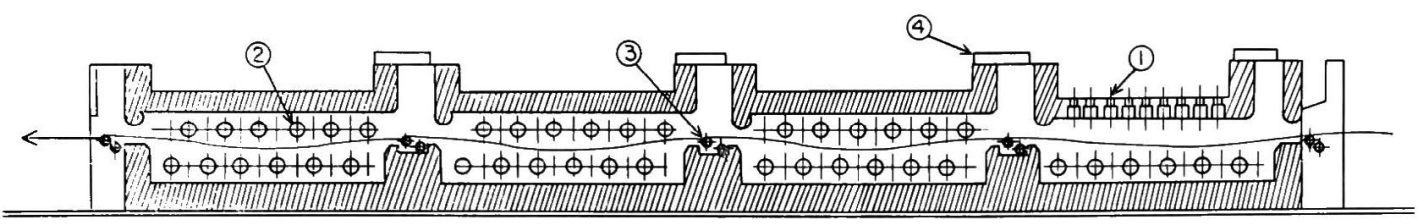

図17高速加熱併用急速加熱式カテナリー焼鈍炉

(1)：高速加熱用ジェットガスバーナー (2)：燃焼ガスバーナー

(3)：炉内ストリップ支持ローラー (4)：炉内圧調整ダンパー

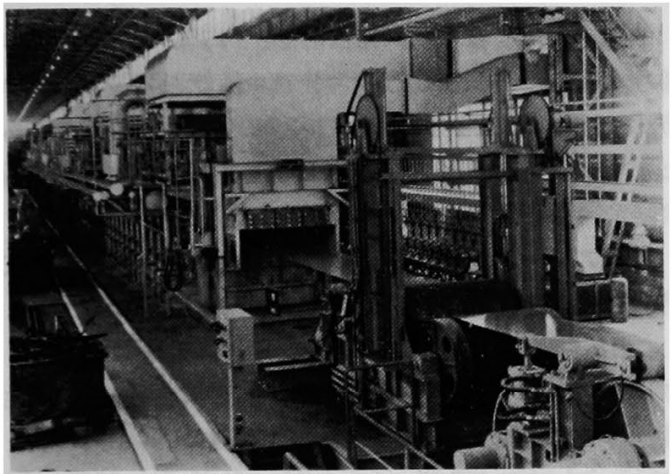

写真 3 高速加熱併用急速加熱式カテナリ焼鈍炉

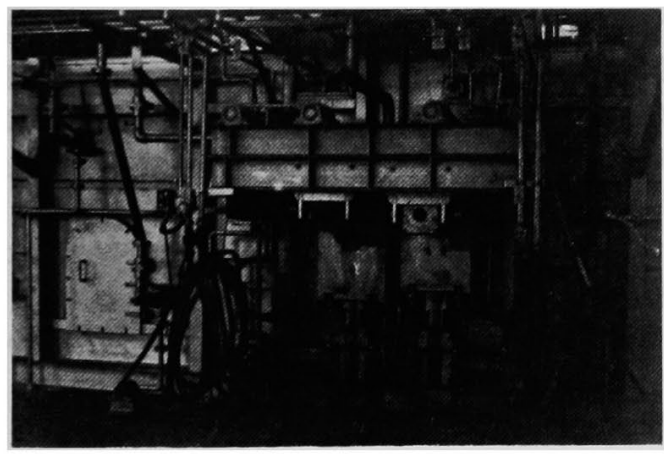

写真 4 カテナリー炉炉内支持ロール部

しい技術的進歩を必要とした，竪形炉では垂直通板に要 する上下部支持ロールは, 表面疵発生防止のためにゴム ライニングロールを使用するため, 下りパスで加熱泠却 サイクルを完了させる必要がある. 炉内張力は, 加熱帯 における高温状態の材料許容張力に制約され, 冷却帯を 含めた該当長さの材料自重も考慮して張力制御の設計を 行なわなければならない、したがつて垂直部の高さが制 限され，目標処理能力を確保するために安定した急速加 熱および急速冷却法が必要であり, 炉体の構造, 加熱バ ーナ一の選択とその配列, 冷却装置などに新しい技術が 採用されている. 一方, 燃焼制御法にも進歩があり, 当 初カテナリー炉では on-off 制御が行なわれていたが,
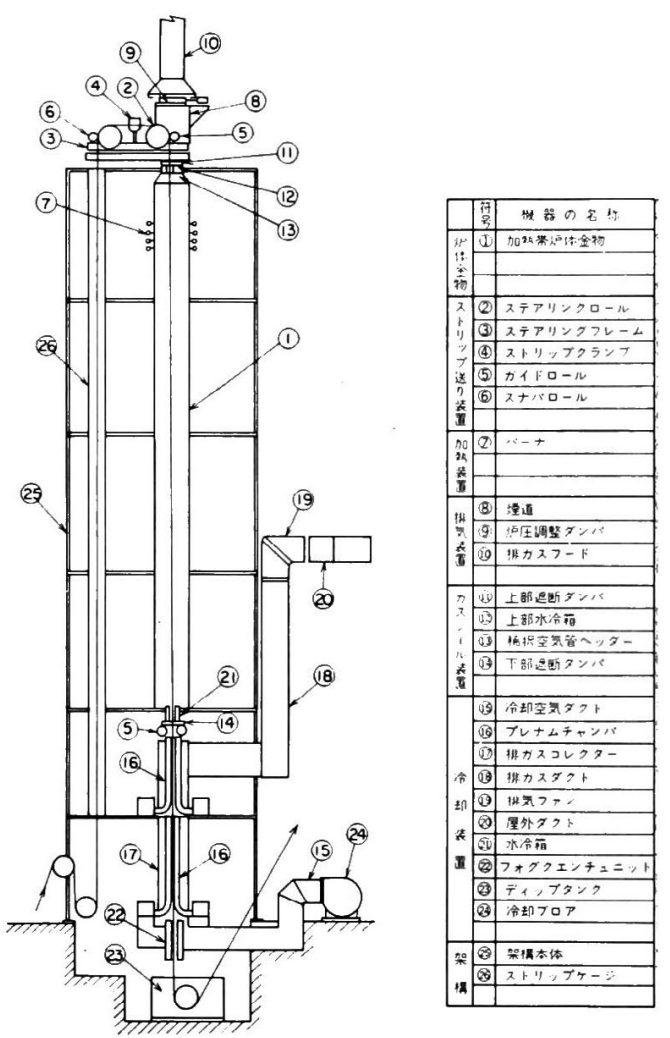

図 18 堅型焼鈍炉構成図

最近ではリアルタイム式に PID 制御が通常採用されて いる．焼鈍温度は従来から炉温による間接的制御が行な われているが，急速加熱化が進むにつれて，究極的には 真の材料温度を測定して燃焼コントロールを行なう直接 的制御に進むべきであり，今後の課題である.

光輝焼鈍は無酸化焼鈍のため，その製品は泠間圧延に より得られる平滑な光択面を損なうことなく焼鈍が行な われ，美簏な表面品質と，優れた耐食性が得られる.わ が国においては昭和 37 年に初めて導入された. その後 ストリップの表面保護皮膜の発達や各種プレス技術の進 歩などにより，最終需要家まで製造時の表面品質が維持 
できること, 研糜工程の省略が可能なことから需要が増 大し，国内において現 在光輝焼鈍炉は 8 基稼働してい る.

設備的には，ストリップの炉内センタリング，フラッ パリング(板の摇動現象), カヌーイング (板幅方向の湾 曲現象）などの防止技術の進歩により炉内発生疵の防止 が可能となり, 大型化による生産能力の向上がなされて いる. また付带主要設備である脱脂装置においてストレ ートミネラルオイル以外にソリブルオイルの冷間圧延油 が採用されるようになつたので, 有機溶威脱脂とアルカ リ洗浄脱脂の 2 種類が使用されている.

(2) 今後の展望

（a）直火式焼鈍炉については，脱スケール技術の進 歩と相俟つて生産性向上と, より安定した品質が得られ るように, 急速または高速加熱方式の開発研究が一層推 進されるであろう.

(b) 光輝焼鈍炉は, 後処理としての脱スケールを必 ずしも必要としない（鋼種による）ので最近の公害問題 に対して有利である. 廃酸処理設備とそのランニングコ スト，また，焼鈍酸洗口スがないので製造コスト，歩留 上からも有望であり, 今後直火式焼鈍酸洗ラィンに代り 採用範囲が拡大されるであろう.

\section{5 脱スケール}

冷間圧延機の進歩にともなつて，ステンレス鋼冷延龬 帯の量産体制が確立され，必然的に焼鈍および脱スケ一 ル設備の大型化, 高能率化が要請されるようになつた. 一方, ステンレス鋼冷延鋼帯の表面仕上げは酸洗によつ て左右される. 最近はとくに多種多様の表面仕上げが要 求されるようになりつつある.これらの要請に対処する ため, 脱スケール方式における多くの設備および技術面 の開発が行なわれ，実用化されつつある. 以下に酸洗方 式の進歩の経緯ならびに最近開発され実用化されている 酸洗方式の代表例を紹介する.

ステンレス鋼冷延鋼帯製造の初期においては, 焼針設 備と脱スケール設備とは別個に設置され, それぞれ単独 に作業が行なわれていたが，処理能力の増大が要請され 始めた昭和 30 年代初頭より, 焼鈍設備と脱スケール設 備とを一体化した設備, すなわち連続焼鈍酸洗設備に変 遷してきた。

初期の連続焼鈍酸洗設備においては, 一般的に無機酸 $\left(\mathrm{HNO}_{3}, \mathrm{HF}, \mathrm{H}_{2} \mathrm{SO}_{4}, \mathrm{HCl}\right.$ など) 単味またはこれらの 混酸, さらにこれに電解法を併用した浸漬方式による酸 洗が行なわれており，これらのなかで硝酸と弗酸との混 酸, 硝酸電解および硫酸電解の 3 者を組み合わせた酸洗 方式がもつとも多く用いられていた。
これらの酸洗方式では処理能率が上がらず，処理能率 の增大を図るためには, 必然的に酸洗槽をを長くせざるを えず，また鋼帯が酸液中に長時間浸漬されるため素地金 属が侵食され, 鋼帯表面の美観を損なうという久点があ つた.

これらの欠点を補なうものとして昭和 23 年頃より米 国で実用化されていた溶融アルカリ塩法が，わが国にも 導入され，昭和 38 年頃より本格的に利用されるように なつた.

溶融アルカリ塩法は, 無機酸酸洗および電解酸洗との 組み合わせにより優れた脱スケール性能を発揮し，この 方式の採用により，脱スケール能率が大幅に増大される とともに美麗な表面肌が得られるようになつたが，表面 欠陷が発生しやすく，また原価高などの欠点もある.

溶融アルカリ塩方式の代表的な脱スケール設備の構成 略図を図 19 に示す.

つぎに中性塩電解法が挙げられる. 中性塩電解法は, オーストリアのルーッナー社で開発されたもので, 中性 塩 $\left(\mathrm{Na}_{2} \mathrm{SO}_{4}\right)$ 電解と, 硝酸または混酸 $\left(\mathrm{HNO}_{3}+\mathrm{HF}\right)$ と の組み合わせによる脱スケール法である.この方式は昭 和 43 年にわが国に導入され広幅ステンレス鋼鋼帯脱ス ケール設備として，世界で最初に実用化された，中性塩 電解法は，原理的には硫酸電解法と近似しているが，電 解槽の構造, 電極の配列および電解液の循環方式など設 備的に大幅な改善が加えられ，脱スケール能率の向上を 図つた点が大きな特徴である。

中性塩電解方式の脱スケール設備の構成略図を図20に 示す.

溶融アルカリ塩法の優れた脱スケール性に着目し, か つ，その欠点を補つた画期的な脱スケール方式として， 昭和 46 年にわが国で開発され，実用化されたアルカリ 塩膜法 (SHF 法) がある.

この方式は原理的には溶融アルカリ塩法と同様であ り，設備構成も酷似しているが，処理方法がまつたく異 なつている.すなおち, この方式は溶融アルカリ塩法の

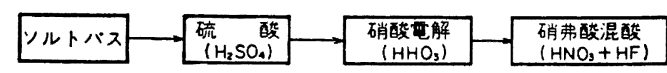

因19亚溶融アルカリ塩方式の脱スケール設備構成略困

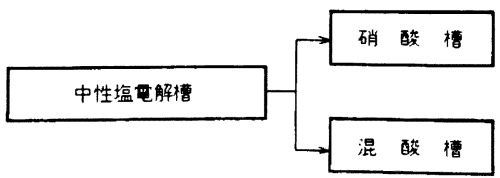

図20 中性塩電解法式の脱スケール設備構成略図 
ごとき浸漬方式ではなく，スプレー方式によりアルカリ 液を鋼帯表面にスプレーし，鋼帯の保有熱により反応さ せ, 溶融アルカリ塩法と同様の脱スケール効果が期待で きるむのである.この方法では通板する鋼帯の種類によ つては, スプレー条件を瞬時に变更することが可能であ り, さらにスプレー方式であるため, 紘急自在の操作が 可能なため，アルカリ液のムダが少なく矨率的である.

アルカリ塩膜方式の脱スケール 設備の構成略図を図 21 に示す.

脱スケール方式の進歩の経稦ならびに現況について述 べたが，いずれの方式にも共通していえることは，廃酸， 廃ガス処理の問題であがて, 現状の中和処理法に变わる 回収処理方法の開発が今後の課題であり, この成否によ つて, 脱スケール方法もかなり変わつた方向に進展する むのと考えられる.

\section{6 連秸前断}

ステンレス鋼の刖断は最終工程として, 形状矯正, 設 定寸法 (幅·長さ) 切断, 表面検査, パイリングの自動 化などが要求され，これらの要求に応じて，連続剪断設 備の機器の構成が種々考えられ, 品質, 能率の向上に著 しい進展がみられる.

（1）連続剪断設㣁の進歩

最近の連続剪断設備の構成は, 能率, 品質の向上, 省 力化に重点がおかれ, 設備の構成は, ペイオフリール, 溶接装置, サイドトリーマー, テンションレベラー, 表 面検査機, 合紙挿入装置, シャー・パイリング装置など からなつている. これらの配置の1例を図 22 に示す.

この構成設備のうちおもなものについてつぎ述べ る.

（i）ローラーレベリング設備

従来は切板にてストレッチャー(引張矯正機)で形状矯 正していたこともあつたが，最近では剪断ライン中にレ
ベラーを組みこむことにより，コイルフォームで形状矯 正を行なう方法をとるようになつた。 また，ステンレス 鋼は比較的, 引張り強さ, 硬度, ともに高く, レベラー としてはロール径を小さくする必要が生じ，多段レベラ 一が適用され，とくに薄板に関してはテンションレベラ 一が使用されるようになり，一層形状矯正の効果をあげ ている.

ステンレス鋼は疵防止がとくに重要であるが，押し込 み疵に関しては，ウエットレベリングによる方法で，ほ ほ完全に防止でき，チャッターマークに関しても，ロー ルの組み込み方法の改善, およびレベラ一制御機器の進 歩にともない解決され，問題なく操業できるようになつ てきた。

(ii) 連続シャ一設備

要求される長さに, 連続的に 剪断していく方法とし て, 薄板については, 従来のフラットカットシャータイ プから,さらに能率と精度を向上させる目的でフライン グシャーが適用されるにいたり，ライン速度も $100 \mathrm{~m} /$ $\min$ と大幅に向上し, 自動表面検査機, 自動合紙挿入装 置, 自動パイリング, などの開発とあいまつて, 今後さ らにスピードアップしていくものと考えられる.これら の前断方法は，いずれも，ステンレス鋼の表面を疵つけ ないように，また，剪断時に折れ疵がでないように工夫 されており，剪断方法としては表 8 のごときタイプとな つている.

\section{(iii) パイリング装置}

所定の長さに剪断された板を，自動的にパイリングす る方法としては，従来の人力によるパイリングの方法か ら, 静電気を利用した自動合紙挿入装置の開発によつて 昭和 44 年頃から, 国内においてもエャークッション, または，バキュームを利用するなどの，機械的パイリン グ方法に变わり効果的にパイリングを行なうようになつ

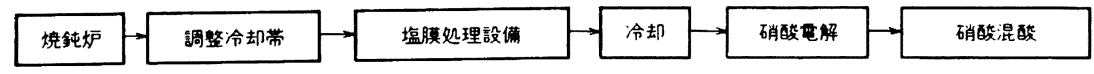

図21 アルカリ塩膜法式の脱スケール設備構成略図

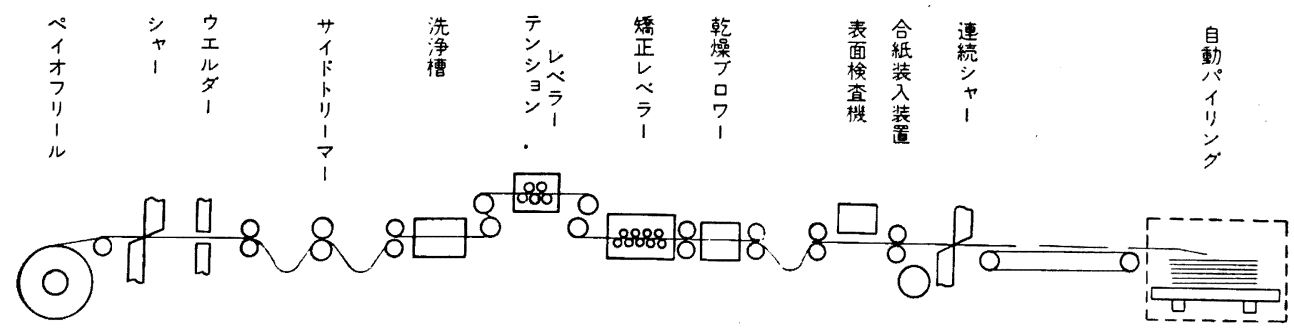

図22連続岁断設備構成図 
表 8 連続シャ一其断方法

\begin{tabular}{|c|c|c|}
\hline ステンレスの板厚 & シ+-タイプ & 方 \\
\hline $2.0 \sim 9.0 \mathrm{~mm}$ & ダイシ+一方式 & $\begin{array}{l}\text { コイルのスビードに合わせて, シャー刃を平行移動 } \\
\text { させ, 所定の長さに罗断する. }\end{array}$ \\
\hline $0 \cdot 2 \sim 2 \cdot 0$ & フライングシ + - & $\begin{array}{l}\text { 刃物を摇動させて, コイルのスピードに合わせ, 所 } \\
\text { 定の長さに弯断する. }\end{array}$ \\
\hline " & フップカットシャー & $\begin{array}{l}\text { 所定の長さ板を送り，板そのものを停止させて崩断 } \\
\text { する. }\end{array}$ \\
\hline
\end{tabular}

てきた

（2）連続剪断設備の今後の動向

ステンレス鋼の連続剪断設備の現状として, 形状矯正 寸法精度については, 初期の目的を達成し，今後の動き は，表面検査および棝包を，この連続芴断設備に組み込 むことにより，省力および工程の単純化を行なおうとし ている、したがつて, 自動表面検査機の開発，形状検出 機，自動梱包ラインの組込みなどが積極的に検討され， すでにその一部はかなり実用化の段階に入つている.

\section{7 その他}

最近注目をあびている表面保護被膜と自動表面検査機 について概略ふれることにする.

（1）ステンレス鋼表面保護被膜

ステンレス鋼の成形加工の進歩につれて，加工工程の 合理化のために BA，No 4, HL などのステンレス鋼特 有の表面仕上をそのまま生かして成形加工後の研摩工程 をできるだけ削減しようとする傾向が強まり，保護被膜 を被覆したステンレス鋼板，および鋼带の要望が強まつ てきた．従来表面保護被膜としては，クラフト紙や，ビ ニールの膜に粘着材を塗布したものなどがあつたが，品 質面, 経済性, 生産性などの点からストリッパブルペイ ント(制離可能)が注目されてきた.

この製品をビニールコート品，またはストリップガー ド品といつている.

（i）ビニールコート製品の特長

表面保護被膜の性能を支配するものは, 塗料および塗 装, 焼付けの方法である. 表面保護被膜として使用され る塗料は短時間で焼き付けが可能であり，加工性にすぐ れ，仕上り染膜は光沢があり美麗でなければならない， これらの要求を満足させる種々の塗料が開発され，それ ぞれの特長を認められて使用されているが，ほとんどが オルガノゾル系塗料が採用されているようである。この 塗料には

（a）塗膜が強じんで十分な伸び率，たわみ性および 適当な付着性を持つているので各種の加工に耐光，素材
の傷つきを防止するだけでなく，深絞り性(限界絞り性) を向上させる.

（b）塗膜が透明であるため塗装後の金属の仕上面の 検査が可能である.

（c）プレス加工中に塗膜がはがれたり，切れたりす ることがないので連続作業性がよい。

（d）塗膜の形成温度が約 $180^{\circ} \mathrm{C}$ 前後であるため, ステンレスの性質および形状などをこわさない.

(e ）成形加工後の塗膜の制離作業は人手により簡単 に㭔離することが可能である.

（f）希酸, 希アルカリなどの腐食性化学薬品に耐光 3.

(ii) 最近のストリップガードの動き

上記の塗料は塭化ビニールの樹脂を主体にしているた め, 直射日光により分解し, 塩酸が出て，ステンレスの 発錆の原因となる.したがつて成形加工後, 膜を剩離す る必要があるが，この制離作業を省力するために溶刘可 溶型の保護被膜が開発されつつある．現在，一部使用さ れているものとして，アルカリ可溶型，ガソリン可溶型 などのタイプのものが開発されている.このタイプは小 物を大量に処理する場合適している. しかしほかの場合 にはやはり人手による涂離作業の方が有利のようであ る.

\section{（2）表面検査機}

近年のステンレス製造設備は，諸技術の進歩に伴いラ インスピードは高速化しつつある.このため高速下にお ける鋼板表面疵の検査方式の確立が強く要望され自動検 査機の開発が各方面で推進され，一部ではすでに実用化 されつつある現状である．以下その現状についての概要 を示す。

(i) 検查方式

鉄鋼で用いられている自動表面検查機の方式は，光学 的方法の走查飛像方式と走査飛点方式が主体である.

(a) 光学的走查飛像方式

この方式は図 23 に示すように被検面より反射した光 


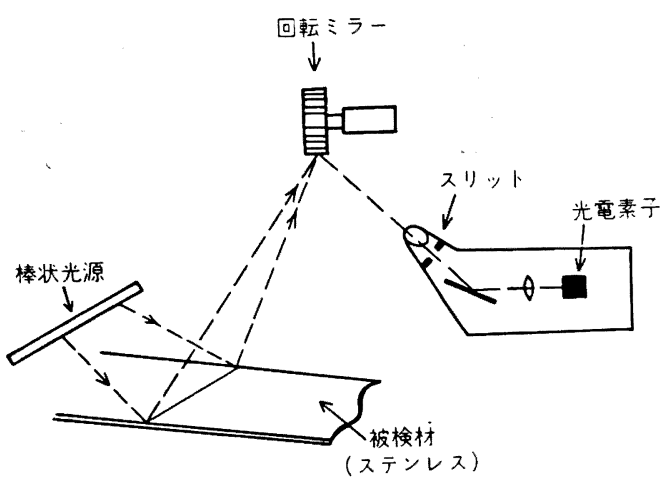

四23光学的走査飛像方式原理図

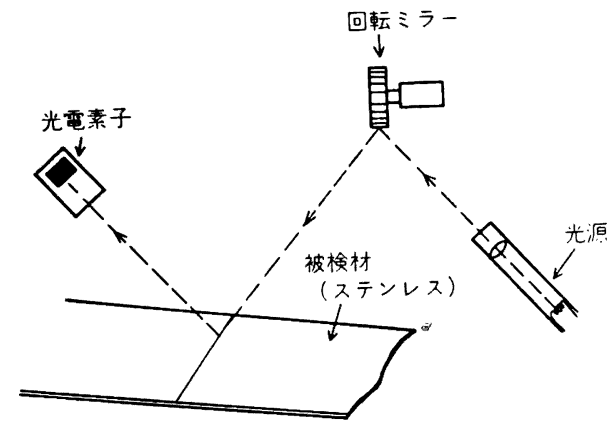

四24光学的走查飛点方式原理困

を回転ミラーで反射し，スリットを通して光電素子によ り光電変換する. 光電素子には被検面のごく小区域から の光が入射されるだけであるが，回転ミラーの回転によ り板幅全体に移動し, 全面走査される.

(b) 光学的走査飛点方式

この方式は図 24 に示すように, 光源と受光部の位置 が飛像方式と入れ替つた方式である.この方式では，1 ユニットの検査幅は限られてくるため, 検査幅に応じて 数ユニット設置される.

(ii) 欠陥検出原理

ステンレス表面の正常部と欠陥部の反射光量の差, す なわち，変化分を求めて欠陷を検出するものである.

(iii) 今後の動き

自動表面検查機は目視検查と比較した場合, 総合的な 判定能力面では欠陷種類の認知ができないなどの大きな 問題点を有している. しかし，使用方法によつてはライ ンスピードに対する良好な追従性, 安定した検出能力な どにより, 実用化の例も増加の傾向にある. 今後欠陥種 類の認知などの開発が進むことにより，実用化の範囲む 拡大されてくるものと考える.

\section{交献}

分 塊

1) F. K. Bloom and D. L. Loveles: The Iron Age, June 20, (1957), p. 97

2) 長谷川: 鉄と鋼, 51 (1965) 6, p. 1162

3 ) Kickiro SAIgo: Steel Times, March (1968), p. 162

4) 日本陶器 $\mathrm{KK}$ 資料：NTG-150H

熱 延

1）日本鉄鋼協会：圧延理論とその応用，（1971）， p. $112 \sim 115$, p. $267 \sim 276$

2 ）日本鉄鋼協会: 鉄鋼製造法, (1972), p. 137～144 p. $587 \sim 606$

3) 長谷川: ステンレス鋼便覧, (1959), p. 522〜531

4 ) 原口, 谷口, 馬場: 日立評論, 52 (1970) 5. p. $13 \sim 19$

5 ）桂：压延技術，(1971)，p. 72～73. p. 96〜121 冷 延

1) 石田, 飯泉：日新製鋼技報，21（1969), p. 70 94

2 ）西村，ほか：日新製鋼技報，25（1971)，p. 1 9

3) ステンレス協会: ステンレス, 15 (1971)11, p. $16 \sim 20$

4) 岩尾, ほか：塑性と加工, 8 (1967) 5, p. 248〜 255

5) 水野：塑性と加工， 7 (1966) 9, p. 447〜454

6 ）三井，分田：川崎製鉄技報，2（1970）3, p. $67 \sim 75$

7 ) Sheet Metal Ind.: 48 (1971) 5, p. 402

8 ) Sheet Metal Ind.: 46 (1969) 5, p. 407 411

9) Draht: 21 (1970) 6, p. 441

10）井口：金属, (1972) 新春合併号, p. 115

11）浦山，ほか：川崎製鉄技報，4（1972）1， p. -49 $\sim 59$

12) S. Friedlander: Iron and Steel Eng. 38(1961) 5, p. 85

13）深瀬：特殊鋼， 21 (1972) 5, p. 35 40

14）志賀，北島：日新製鋼技報，25(1971),p. 10 17

15）三菱重工技報，(1968）6， p. 132～133

16) 長谷川: ステンレス鋼便覧，p. 765〜777 (日刊工業新聞社)

17) 特許公報：S 38-12162

18）パーカー商事KK資料：KOLEN No 1 and Alloy Descaling Process

19）日商岩井KK資料：Rolling Mills ESP Gage Control System

20) 柳：鉄と鋼， 43 (1967), p. 988〜989

21）高木: 鉄と鋼, 50 (1964), p. 637〜639

22) Thor pea FaIRmanl: Iron Steel Inst., (1965) 203 p. 922 929

23) Galvano: 34 (1965), p. 359 364

24）曾田：塑性と加工， 10 (1969) 107，p. 853〜862

25）日下，平沢：塑性と加工， 8 (1967) 78, p. 374 $\sim 380$

26）平松，山本：住友機械技報，18（1970）49, p. 34 


\section{$\sim 44$}

27）平松，山本：住友機械技報，18（1970） 50 , p. $21 \sim 29$

28）平松，山本：住友機械技報18（1970） 51 , p. $16 \sim 20$

29）曾田, 大島：機械試験所所報, 15 (1961) 4, p. $194 \sim 229$

30）赤松, 森田, ほか: Omron Technic, 5 (1967), p. $293 \sim 301$

31）宮川，ほか：製鉄研究，276 (1967), p. 43〜52

32）佐藤：日新製鋼技報，14 (1966)，p. 74 78 